\author{
Universidade de São Paulo \\ Faculdade de Filosofia, Letras e Ciências Humanas \\ Departamento de Letras Modernas \\ Programa de Pós-Graduação em Estudos Lingüísticos e Literários \\ em Inglês
}

\title{
O poder vai dançar de Tim Robbins: \\ História, avanços e limites
}

Neyde Figueira Branco

São Paulo

2011 


\author{
Universidade de São Paulo \\ Faculdade de Filosofia, Letras e Ciências Humanas \\ Departamento de Letras Modernas \\ Programa de Pós-Graduação em Estudos Lingüísticos e Literários \\ em Inglês
}

\title{
O poder vai dançar de Tim Robbins: \\ História, avanços e limites
}

Neyde Figueira Branco

Dissertação apresentada ao Programa de Pós-Graduação em Estudos Linguísticos e Literários em Inglês do Departamento de Letras Modernas da Faculdade de Filosofia, Letras e Ciências Humanas da Universidade de São Paulo, para obtenção do título de Mestre em Letras.

Orientador: Prof. Marcos César de Paula Soares

São Paulo

2011 
AUTORIZO A REPRODUÇÃO E DIVULGAÇÃO TOTAL OU PARCIAL DESTE

TRABALHO POR MEIO CONVENCIONAL OU ELETRÔNICO, PARA FINS DE ESTUDO E PESQUISA, DESDE QUE CITADA A FONTE. 
Catalogação na Publicação

Serviço de Biblioteca e Documentação

Faculdade de Filosofia, Letras e Ciências Humanas da Universidade de São Paulo

Branco, Neyde Figueira

O poder vai dançar de Tim Robbins : história, avanços e limites / Neyde Figueira Branco ; orientador Marcos

César de Paula Soares. - São Paulo, 2010.

108 f.; il.

Dissertação (Mestrado) - Faculdade de Filosofia, Letras e Ciências Humanas da Universidade de São Paulo. Departamento de Letras Modernas. Área de concentração: Estudos Linguísticos e Literários em Inglês.

1. Cinema - Estados Unidos. 2. História social. 3. Arte política. 4. Robbins, Tim. I. Título. II. Soares, Marcos César de Paula.

CDD 791.430973 


\section{FOLHA DE APROVAÇÃO}

Nome: Branco, Neyde Figueira

Título: O poder vai dançar de Tim Robbins: História, avanços e limites

Dissertação de mestrado, pelo Departamento de Letras Modernas, Área de Estudos Lingüísticos e Literários em Inglês, da Universidade de São Paulo, sob orientação do Prof. Dr. Marcos César de Paula Soares.

Aprovada em:

Banca Examinadora

Prof. Dr.

Instituição:

Assinatura:

Prof. Dr.

Instituição:

Assinatura:

Prof. Dr.

Instituição:

Assinatura: 


\section{Agradecimentos}

Ao Professor Dr. Marcos César de Paula Soares pela confiança em meu trabalho, pela orientação presente e o auxílio em vários momentos, por todos os filmes e livros emprestados e pelas inúmeras oportunidades de trocas de idéias, de reflexão e de apresentação e discussão de meu trabalho.

Ao Conselho Nacional de Desenvolvimento Científico e Tecnológico (CNPq), pela bolsa concedida durante parte do mestrado, que possibilitou maior dedicação à pesquisa.

Aos funcionários do Departamento de Letras Modernas, em especial à Edite, pela ajuda constante e por toda a assistência prestada durante esses anos.

Ao professor Dr. Sergio de Carvalho, pela leitura e discussão de minha pesquisa na minha qualificação, além das dicas valiosas para meu entendimento de Brecht e para o andamento do meu trabalho.

Ao professor Dr. Daniel Puglia, pela leitura atenta e discussão de minha pesquisa na minha qualificação, assim como pelas palavras de incentivo e preciosas sugestões para a continuidade de meu trabalho.

Ao grupo de estudos de Literatura e Cinema, por todas as discussões, críticas e conselhos dados em nossos encontros. Pelas oportunidades de aprendizado com o trabalho dos colegas e de debates sobre textos, filmes, peças e tudo mais. 
A todos os companheiros do Coletivo Agir, por compartilharem ideais e objetivos, pela união para tentar aproximar teoria e prática.

À Patrulha da Ajuda (Cris, Elder, Elton, Maira e Roberta), pela ajuda imensurável no desenvolvimento de meu trabalho, por cada frase lida e discutida, por cada sugestão, crítica e questionamento. Pela oportunidade de aprender mais e mais ao ler os seus trabalhos. Pela amizade verdadeira que se torna cada dia mais forte, por todas as vezes que nossos encontros provaram que seis cabeças pensam melhor que uma, por tornarem a vivência acadêmica algo tão gostoso, divertido e nada solitário.

A meus queridos familiares e amigos, por todo carinho, torcida e por compreenderem minhas tantas ausências. Em especial a meu avô e padrinho, Luiz Dantas Cruz.

À minha irmã, por sua amizade, pelas conversas, por se esforçar para entender minhas escolhas e estar sempre ao meu lado.

Ao meu pai, por seu exemplo de trabalho árduo e perseverança. Por me ensinar a ser forte e me dedicar para realizar tudo que eu idealizar.

Ao Fabio, pela constante compreensão, apoio e incentivo. Pelo carinho e companheirismo sem tamanho, que fizeram essa caminhada se tornar muito mais leve e mais fácil.

À minha mãe, por simplesmente tudo. Por despertar em mim a paixão pelos estudos desde sempre, pelo incentivo, apoio e amizade e, principalmente por acreditar em mim ao longo de toda minha vida, mesmo que algumas vezes nem eu mesma tenha acreditado. 
Mas a questão é: nosso desemprego

Não será solucionado

Enquanto os senhores não

Ficarem desempregados!

(poema Esse Desemprego! de Bertolt Brecht)

Desconfiai do mais trivial,

na aparência singelo.

E examinai, sobretudo, o que parece habitual.

Suplicamos expressamente:

não aceiteis o que é de hábito como coisa natural,

pois em tempo de desordem sangrenta,

de confusão organizada, de arbitrariedade consciente,

de humanidade desumanizada,

nada deve parecer natural

nada deve parecer impossivel de mudar.

(poema Nada é impossível de mudar, de Bertolt Brecht) 


\section{Resumo}

Esta pesquisa se utiliza do filme $O$ poder vai dançar (Cradle will rock, 1999), dirigido por Tim Robbins, para entender a História, os avanços e limites de dois momentos históricos: a década de 1930 e a de 1990 nos Estados Unidos. Definido como uma história "predominantemente verdadeira", o filme apresenta personagens e fatos reais e fictícios, que se alternam e se relacionam. Ele é composto por uma série de narrativas, aparentemente fragmentadas e desconexas, mas cujas relações são construídas em todo o seu decorrer.

De modo geral, podemos dizer que o filme retrata a década de 1930, momento de potencial revolucionário na História dos Estados Unidos, uma vez que a crise econômica potencializou e tornou visíveis os problemas decorrentes do sistema capitalista. Em seu intento, o diretor se aproxima da concepção benjaminiana de História, à medida que, mais do que simplesmente reproduzir a narrativa desse período, opta por se apropriar de um momento explosivo do passado, carregado de elementos em comum com o presente, e utilizar a citação do passado como fonte de inspiração no combate presente. Ou seja, parte desse passado para na verdade dizer algo sobre a realidade em que está inserido, da década de 1990. Assim, ao pensar sobre esses contextos históricos, nos possibilita refletir sobre suas características, motivações e conseqüências.

Para tanto, Tim Robbins se utiliza de elementos do teatro épico, e não apenas retrata os elementos históricos do período, mas busca principalmente provocar uma reflexão por parte da audiência. E tal reflexão vai além do entendimento da história, avança sobre questões como o reconhecimento pelo artista de sua condição de proletário da cultura e sobre o limite que se coloca entre fazer arte paga por empresas e a prostituição, entre outras.

Palavras-chave:

Arte política Cinema e sociedade Tim Robbins Década de 1930

Década de $1990 \quad$ Estados Unidos 


\begin{abstract}
This research makes use of the movie Cradle will rock (1999), directed by Tim Robbins, to understand the History, progresses and limits of two historical periods: the decades of 1930 and 1990 in the United States. Defined as a "(mostly) true story", the movie presents real and fictional characters and facts, which are alternated and connected to each other. It has a series of narratives, aparently fragmented. However, its connections are built in the course of the movie.
\end{abstract}

In general, we can say that the film portrays the decade of 1930, moment of revolutionary potential in the History of the United States, as a result of the economical crisis, that made visible all the problems deriving from the capitalistic system. In his intent, the director approaches the conception Benjamin has of the History, as he chooses to go beyond than only narrate the facts of the period and decides to appropriate of such an explosive moment of the past, replete of elements in common with the present, and use the citation of the past as a source of inspiration in the current battle. That is, uses the past in order to say something about the reality he experiences in the decade of 1990. In this manner, we can consider these historical periods and reflect on its characteristics, motivations and consequences.

In order to do that, Tim Robbins makes use of elements of the epic theater, and not only depicts the historical elements of the period but also tries to provoke the audience and make them reflect about the facts and elements he exposes. These reflections surpass the understanding of the History and reaches questions such as the recognition of the artist of his condition of proletarian of the culture and the limit between making art sponsored by companies and the prostitution of the artist, among other.

Key words:

Political Art Cinema and society Tim Robbins Decade of 1930 Decade of $1990 \quad$ the United States 


\section{Sumário}

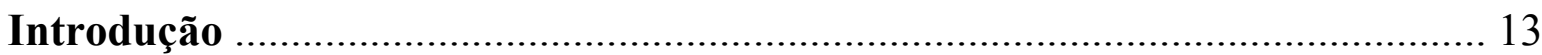

Capítulo 1 - A História em O poder vai dançar............................................... 17

1.1. Relação do espectador com a arte .................................................................... 18

1.2. Artistas como proletários da cultura …..................................................................... 33

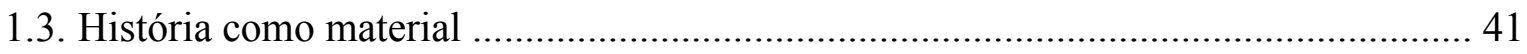

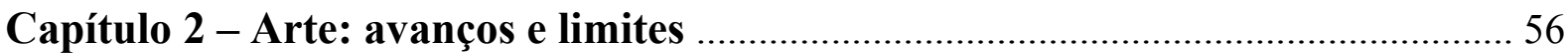

2.1. Tommy Crickshaw e o vaudeville .................................................................. 59

2.2. Diego Rivera e seu mural no Rockefeller Center ................................................. 67

2.3. The cradle will rock e o Federal Theatre Project .................................................. 80

Conclusão - A História de $\boldsymbol{O}$ poder vai dançar...................................................... 97

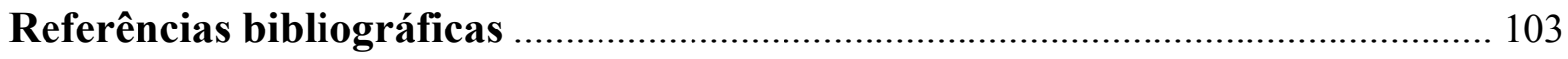




\section{Introdução}

O Poder vai Dançar (Cradle Will Rock, 1999) é um filme escrito e dirigido por Tim Robbins, que é mais conhecido pela sua carreira como ator, mas desenvolveu também três trabalhos como cineasta, em que se percebe claramente uma preocupação com aspectos da sociedade e uma posição esquerdista ao tratar as questões que propõe.

Robbins não é apenas um cineasta progressista, cujos filmes têm conteúdo que vai na contramão da produção essencialmente comercial de Hollywood. Ele é também ativo em uma série de movimentos políticos e sociais, participando de protestos, discursando, envolvendose de maneira efetiva.

Além desse aspecto de sua vivência política, faz-se necessário também enfatizar que, em seu trabalho artístico, se utiliza de materiais resgatados de uma tradição a que se filia. Podemos destacar como parte dela os filmes dos diretores Orson Welles e Robert Altman, que não são utilizados apenas como fonte de formas ou de maneiras de filmar, mas principalmente no tocante à sua posição no debate das forças produtivas. Seu modo de trabalho, baseado na construção coletiva da obra de arte, reflete nos conteúdos e na forma como tais conteúdos são tratados, assim como na sua percepção e recepção por parte do público. Outra influência fortemente marcada na obra cinematográfica de Robbins é o teatro épico de Brecht. Como veremos ao longo desta dissertação, para tratar os temas e eventos selecionados pelo diretor, é dada uma abordagem épica às narrativas, uma vez que elas não se adequariam aos contornos da forma dramática.

Desse modo, o filme se caracteriza por um movimento contrário ao do cinema clássico, que buscaria levar o espectador a uma identificação com as personagens no nível das 
emoções. Em O poder vai dançar, ele é colocado em face das personagens que estão inseridas em um contexto no qual nos é possibilitado, desde esse principio, estabelecer relações e fazer reflexões. A própria forma do filme, composta a partir de múltiplas narrativas, dificulta uma identificação catártica do espectador com o enredo e personagens, que traria um desligamento em relação à realidade.

Esses elementos apontados são característicos do trabalho do diretor Robert Altman, com quem Tim Robbins teve contato durante sua atuação no filme $O$ jogador $^{I}$, trabalho considerado por Robbins como bastante significativo em sua carreira ${ }^{2}$. O que caracteriza fortemente a filmografia de Altman é a construção coletiva de seus filmes, que produz resultados extremamente marcantes e produtivos.

\begin{abstract}
Quando um ator vem me encontrar, é claro que tenho uma idéia de como o personagem vai ser. Mas eu sempre quero ver o que o ator trará para acrescentar. Se a visão fosse apenas minha, uma única visão, não seria nada bom. Ela é a combinação do que tenho em mente, quem o ator é, como ele se adapta ao personagem e como eu me adapto ao personagem. É isso que faz um filme. ${ }^{3}$
\end{abstract}

Ao analisarmos a fortuna crítica de $O$ Poder Vai Dançar, percebemos que as características apontadas nesta introdução não são observadas, havendo freqüentes exigências de natureza dramática e sendo comuns as dificuldades de descrição do filme. Steve Rhodes ${ }^{4}$ afirma que as personagens são estereotipadas, sem levar em conta que na verdade elas se

\footnotetext{
${ }^{1}$ The player (1992), dirigido por Robert Altman.

${ }^{2}$ Entrevista concedida por Tim Robbins à $\mathrm{CBC}$, disponível em http://www.youtube.com/watch?v=co7meNOGjzQ\&feature=PlayList\&p=AF408B79D6E83688\&playnext=1\&pla ynext from=PL\&index=68 (tradução nossa)

${ }^{3}$ Sterrit, D. (org.). Robert Altman: Interviews. Jackson: University Press of Mississippi, 2000. p.129. (tradução nossa)

${ }^{4}$ Rhodes, Steve. Movie Review for Cradle Will Rock. Disponível em http://www.celebritywonder.com/movie/1999 Cradle Will Rock steve rhodes.html (tradução nossa)
} 
constituem enquanto tipos. Janet Maslin afirma que "o filme é grande, corajoso, algumas vezes enlouquecedoramente redutor, que se eleva por puro talento e entusiasmo que superam suas limitações"5. Para ela, há uma simplificação exagerada de personagens, o que pode ser percebido também como uma não consideração da tradição a que o filme se filia. Para Andy Klein ${ }^{6}$ não há nenhuma personagem com a qual a platéia possa se identificar e acompanhar por muito tempo. Sua análise está correta, porém o crítico identifica esse aspecto como um defeito do filme, quando na verdade é produto de uma intenção do diretor. Exemplos de críticos que, como os citados, exigem do filme características do repertório dramático são numerosos mas, para complementar nossa perspectiva, citaremos Dennis Schwartz, que diz:”o filme freqüentemente parece uma bagunça. Ele tem histórias demais acontecendo ao mesmo tempo e personagens demais para conseguirmos acompanhar, com uma atuação nada convincente"7. Além dos aspectos já apontados, ele também dá indícios de uma incompreensão da relação dialética determinante entre as partes do filme entre si, e dessas partes com o filme como um todo.

Há críticas que, apesar de considerarem o filme como uma obra de qualidade, ainda assim encontram barreiras impostas pelas expectativas dramáticas. Isso porque, ao retomar o enredo do filme, por exemplo, demonstram certa dificuldade, em muitos casos simplificandoo, ao dizer que trata da montagem de The Cradle Will Rock, caracterizando as demais narrativas como secundárias. Ao fazer isso, ignoram o fato de que todas as narrativas e personagens têm igual importância, que ultrapassa o nível narrativo para permitir nossa percepção dos aspectos sócio-históricos envolvidos. David Schiff diz que Robbins "centra o filme em dois dos atores da peça, a real Olive Stanton e o ficcional Aldo Silvano, um ítalo-

\footnotetext{
${ }^{5}$ Maslin, Janet. Cradle Will Rock': Panoramic Passions on a Playbill From the 30's. disponível em http://www.nytimes.com/library/film/120899cradle-film-review.html (tradução nossa)

${ }^{6}$ Klein, Andy. Review of the movie Cradle will rock, disponível em http://www.riverfronttimes.com/2000-0119/film/cradle-will-rock/2 (tradução nossa)

${ }^{7}$ Schwartz, Dennis. The unfortunate thing about the film, is that it is not terribly entertaining. Disponível em http://www.sover.net/ ozus/cradlewillrock.htm (tradução nossa)
} 
americano anti-Fascista. Stanton, uma mulher sem teto que nunca tinha estado em um palco, encontra um trabalho como contra-regras no Federal Theater Project, e então toma posse do papel de Moll, como se fosse seu por direito". Mais uma vez o crítico se detém ao nível narrativo e não considera que as personagens são mais um elemento da equação por meio da qual o diretor propõe seus teoremas. Alguns críticos, entretanto, se dão conta de que tais aspectos fazem parte de uma maneira diferenciada de pensar o cinema. Assim, Todd McCarthy afirma que "Cradle é apenas uma das diversas venturas artísticas relacionadas tematicamente para retratar um panorama cultural dinâmico durante um período tumultuado e emocionante." 8

Desse modo, aqueles que assistem ao filme esperando o cardápio do gênero dramático, não são contemplados e entendem tais diferenças como falhas de roteiro. Ao compreender que o número de personagens e de narrativas, além da dificuldade de identificação com os mesmos, são propositais e portanto essenciais para o entendimento do filme, o espectador avança enormemente no entendimento e se aproxima da proposta do diretor, conforme veremos ao longo da dissertação.

No primeiro capítulo procuraremos justamente dar indicações sobre esse modo de ver o filme que é proposto por Tim Robbins, indicando a relação que espera ser estabelecida entre o espectador e a obra. De modo complementar, indicaremos de forma geral o mapeamento das perspectivas em relação ao trabalho artístico e à história do período que retrata o filme, realizado pelo diretor.

No segundo capítulo, a intenção é avançar na análise dos teoremas que Tim Robbins propõe, identificando as possibilidades e limites que se colocam aos artistas Tommy

\footnotetext{
${ }^{8}$ McCarthy, Todd. Resenha sobre o filme O Poder Vai Dançar, disponível em http://www.variety.com/review/VE1117499758.html?categoryid=31\&cs=1 (tradução nossa)
} 
Crickshaw, Diego Rivera e a todos que fazem parte do elenco da peça The Cradle Will Rock.

Por fim, será realizada uma conclusão que buscará relacionar os aspectos indicados ao longo de toda a dissertação, ressaltando o fato de que este é um filme realizado da década de 1990, mas retoma eventos e personagens da década de 1930. Desse modo, indicaremos quais as possíveis motivações para tais escolhas, tentando investigar o que esses dois momentos históricos têm de semelhante. 


\section{A História em $O$ poder vai dançar}

Neste primeiro capítulo buscaremos abordar alguns dos aspectos que nos chamam a atenção em relação à estruturação formal de $O$ poder vai dançar, relacionando tais aspectos formais com o conteúdo que o filme propõe. Desse modo, buscaremos subsídios para a compreensão do modo como devemos assistir ao filme e do posicionamento que devemos assumir para fazê-lo. Discutiremos a princípio três aspectos, a saber: a relação que o público estabelece com a obra de arte e, conseqüentemente, a que o espectador estabelece com $O$ poder vai dançar; a perspectiva sobre os artistas enquanto proletários da cultura; e, por fim, a representação da História como material na construção do filme. Tais aspectos estão presentes não apenas como conteúdos, mas também funcionam como princípios organizadores da cena ao longo dessa obra cinematográfica como um todo.

O filme é composto de diversas narrativas, aparentemente fragmentadas e desconexas, mas que, na verdade, constituem um todo se observarmos os teoremas que sugerem; ou seja, faz-se necessário estabelecer relações por meio da forma e dos conteúdos abordados. Essas relações se tornam ainda mais interessantes por conta da relação frutífera que há entre fragmento e todo, haja vista que uma grande quantidade de informações é condensada em fragmentos do filme, havendo a possibilidade de ver, através de uma parte, o todo.

Mais do que simplesmente analisar a forma de O Poder Vai Dançar, buscaremos demonstrar como a linearidade, as relações de casualidade e o aprofundamento psicológico de personagens individualizadas não acomodam os conteúdos tratados no filme, razão pela qual o cineasta opta por resgatar formas e conteúdos do universo do épico. 


\title{
1.1. Relação do espectador com a arte
}

Começa o filme. Na tela, surge um texto que exerce a função de prólogo, apresentando diversas informações históricas que servirão como base para estabelecermos as relações entre ações e personagens. Esse texto aparece antes de qualquer ação e determina em primeiro lugar o contexto histórico: a década de 1930. Apresenta, em sua primeira frase, o local: Estados Unidos, e o fato de que esse se encontra no período da "Grande Depressão".

Nele lemos:

\begin{abstract}
Alemanha e Itália, não ainda inimigas dos Estados Unidos, adquirem petróleo, borracha e aço das corporações americanas.

Trabalhadores americanos, sem jornada de 40 horas semanais, salário mínimo ou benefícios para a saúde, começam a se dar conta da necessidade de sindicatos. Greves fecham indústrias inteiras.

O governo americano dá andamento ao Works Progress Administration, um ambicioso e diversificado programa para colocar os desempregados de volta ao trabalho. Uma das divisões da WPA é o Federal Theater Project (FTP), que leva teatro de baixo custo para milhões de americanos. ${ }^{9}$
\end{abstract}

O prólogo de $O$ poder vai dançar dá indícios de que ele não se encontra dentro dos padrões do cinema clássico, nos quais a História serviria como pano de fundo e motivação para a ação dramática. Nesses filmes, mesmo que houvesse um texto anterior à ação, o que não é muito comum, ele traria informações a respeito de eventos históricos que influenciaram

\footnotetext{
${ }^{9}$ Todos os trechos do filme utilizados nesta dissertação são tradução nossa.
} 
a vida dos personagens, em termos individuais ${ }^{10}$. Por outro lado, em $O$ poder vai dançar os sujeitos da ação são Alemanha, Itália, os trabalhadores e o governo americano, ou seja, coletividades. Diante dos assuntos selecionados percebe-se a necessidade de um tratamento épico dos fatos, uma vez que eles não caberiam dentro da forma dramática, que representa indivíduos, e não coletividades. Tais fatos são apresentados no filme por meio de uma narração extradiegética ${ }^{11}$, que ao mesmo tempo vai servir como comentário para a ação e esboçar o pano de fundo social. A escolha desses fatos em específico sugere possíveis relações entre diferentes eventos, o que desperta, já inicialmente, a atividade do espectador, que poderá tentar estabelecer essas relações.

Imediatamente após esse prólogo, a personagem Olive Stanton nos é apresentada em close. Ela está deitada, de olhos fechados, e vemos uma inscrição: Outono de 1936. Quando abre os olhos, o plano mostrado pela câmera se amplia progressivamente, por meio de um movimento de traveling e ouvimos uma voz: "Pode rodar"12. O plano é ainda mais expandido e a garota é inserida em um ambiente que dá indícios sobre sua situação: dorme nos bastidores de um teatro e utiliza a cortina como cobertor. Podemos afirmar que, ao mesmo tempo em que Olive abre os olhos para o universo da diegese, os espectadores do filme também são convidados a abrirem seus olhos para os fatos que serão apresentados e a vivenciarem o mesmo processo que ela. Contudo, eles já tiveram um contato com o universo extradiegético a priori e podem levar em conta esse conhecimento prévio obtido através do prólogo para uma observação mais cuidadosa dos fatos.

\footnotetext{
${ }^{10}$ O filme A lista de Schindler (Schindler's List, Steven Spielberg, 1993), por exemplo, apresenta o seguinte prólogo: "In the midst of the mass killings of the Jews by the Nazis in the World War II, Oskar Schindler spent most of his fortune on sheltering them from the persecution. The Nazis accepted an unconditional surrender before long, and the war ended."

${ }^{11}$ Diegese em obras de ficção (literárias, teatrais, cinematográficas, televisivas etc.), refere-se à realidade interna da obra, como criada pelo autor, independente da realidade não ficcional do 'mundo real'. Fonte: Dicionário Aulete. In: http://aulete.uol.com.br/site.php?mdl=aulete digital, consultado em 25/04/2010

${ }^{12}$ No original, "you can roll it"
} 
Olive está atrás da tela, e percebemos essa inversão espacial pelo fato de vermos as imagens ao contrário. Nessa tela, é projetado na diegese um newsreel, forma de documentário curto muito utilizado no início do século XX para apresentação de notícias. A História, assim como no prólogo inicial, assume novamente o papel principal da narrativa, inclusive na composição da cena. O newsreel mostra uma série de notícias, que também colaboram para a constituição do painel dos elementos históricos que nos ajudam a compreender os eventos retratados no filme de forma mais clara. Olive é, portanto, não apenas personagem do filme ao qual assistimos, mas é também espectadora do filme que passa a ser mostrado na tela. Ela e os espectadores de $O$ poder vai dançar são representadas em equivalência estrutural, ao ocuparem posições semelhantes em relação ao newsreel e ao filme, respectivamente. $\mathrm{O}$ ato de assistir às notícias por trás da tela torna essa relação ainda mais interessante, uma vez que podemos entendê-lo como uma sugestão de que os espectadores devem, assim como Olive Stanton, observar o que está por trás da tela, em sentido metafórico, ou seja, devem ver além das aparências dos fatos apresentados, buscando compreender de que forma eles se constituem, por meio de sua historicização. Para fazê-lo, contam com as imagens que visualizam nesse momento, juntamente com as informações que foram apresentadas no prólogo.

A primeira das notícias trata do imperialismo italiano, figurado na invasão da Etiópia. Há referência a um discurso de Benito Mussolini para milhares de pessoas. $\mathrm{Na}$ apresentação dessa notícia percebemos um adensamento da equação que este trabalho visa construir, já que é mencionado mais um grupo de espectadores, aqueles que assistem ao ditador italiano falar. De acordo com o noticiário, seu discurso recorda a glória do Império Romano e convoca o povo a se apossar de terras que pertenciam a eles originalmente. Não vemos imagens desse discurso, mas sim de centenas de soldados marchando. De acordo com 
Walter Benjamin ${ }^{13}$, o fascismo produz uma estetização da política, com o objetivo de tentar organizar as massas de proletários, sem tocar nas relações de propriedade. Para isso, o governo fascista impõe a subjugação e o culto a um ditador. Os valores de culto, portanto passam da obra de arte, para o culto de um líder.

Para tanto, o fascismo se utiliza de elementos da indústria cultural, como o protagonismo, a identificação e o apelo às emoções, por meio de recursos de música e iluminação, entre outros, para efeito de mistificação das massas ${ }^{14}$. O newsreel ressalta também a união e a determinação da população etíope que, apesar de pobremente armada, luta para defender seu país. Nessa notícia é retratado o contexto mundial daquele momento histórico, de avanço e crescimento do fascismo e imperialismo, com o apoio das corporações americanas, conforme apontado no prólogo, e explicitado no filme. Mas é também ressaltada a força da organização popular para defender seus interesses.

A notícia seguinte apresenta fatos semelhantes sob outra perspectiva. Descreve o controle exercido pelos nazistas em relação à produção artística e ao acesso da população às obras de arte, exemplificado no episódio da arte degenerada ${ }^{15}$. O locutor enfatiza que Hitler não conhece arte, mas despreza aquela que retrata a Alemanha de forma negativa e não favorável. Inicialmente são mostradas pessoas em uma exposição de arte, e depois algumas pinturas abstratas. Posteriormente, um oficial com uma suástica nazista no braço apontando para uma obra, e em seguida as pessoas olhando para esse quadro. Tal controle do acesso às

\footnotetext{
${ }^{13}$ Benjamin, Walter. "A obra de arte na era de sua reprodutibilidade técnica". In: Magia e técnica, arte e política: ensaios sobre literatura e história da cultura. São Paulo: Brasiliense, 1994

${ }^{14}$ Adorno e Horkheimer, em seu ensaio "A Indústria Cultural: O Esclarecimento como Mistificação das Massas". In: Dialética do esclarecimento; caracterizam os mecanismos que a indústria cultural se utiliza e os aproximam do fascismo.

${ }^{15}$ Referência à exposição de arte moderna montada pelo Partido Nazista alemão, que apresentava cerca de 650 pinturas, esculturas e gravuras, retiradas dos principais museus do país. Seu objetivo era mostrar ao público que a arte daqueles tempos sofria de uma enfermidade que, por sua vez, estaria conduzindo a vida cultural da humanidade ao colapso. Fonte: Bortulucce, Vanessa Beatriz. A arte dos regimes totalitários do século XX: Rússia e Alemanha. São Paulo: Annablume, Fapesp, 2008.
} 
obras de arte é feito por alguém que detém o poder e tem motivações explicitamente políticas em organizar a referida exposição. É especificado mais um ponto de vista que, como o da platéia do discurso de Mussolini, é interno ao newsreel. Todavia, nesse caso há uma intenção de explicitar o domínio da relação entre público e obra, por meio de um controle acirrado realizado pelo governo nazista. Além disso, essa cena nos chama a atenção para o fato de que tal relação com a obra de arte não é autônoma, mas sim determinada pelas condições sóciohistóricas em que se dá e influenciada pelos interesses das esferas do poder. Destacamos que essa é uma característica comum a qualquer relação entre público e obra, porém, através desse exemplo da Alemanha nazista, conseguimos visualizar a referida influência sob lente de aumento. Isso porque enquanto a intervenção ocorre de maneira dissimulada em outras circunstâncias, em uma ditadura ela é explicitada.

Logo em seguida, o noticiário apresenta notícias locais de forma bem otimista, reforçando o progresso através das “obras grandiosas realizadas por milhões de homens e mulheres desempregados, que voltaram ao trabalho por intermédio da WPA". O final do noticiário trata de uma suposta melhora das condições de vida, reforçando a possibilidade de olhar o futuro com esperança, afirmação ilustrada com a imagem de uma família feliz. Há ainda uma reportagem sobre as novas tendências da moda e a descoberta de um novo nicho de mercado: moda para crianças. Por fim, ouvimos informações sobre o projeto de circo do Federal Theater Project, "o último de uma série de entretenimentos de baixo custo". O locutor completa: "vaudeville, Shakespeare e domadores de leão, trazidos para você pelo tio Sam".

Durante toda a projeção dessas imagens, Olive Stanton olha para a tela em poucos momentos, e parece estar mais entretida com tarefas como colocar a meia ou o sapato. Das notícias, aquela que chama sua atenção por alguns segundos é a que se refere à criação de 
empregos pela WPA. Vemos a imagem do presidente Roosevelt, afirmando que "o medo está desaparecendo e a confiança está crescendo em todos os lados”. Ela pára e presta atenção. Contudo, apesar de as imagens e falas do locutor noticiarem grandes realizações e milhares de empregos criados, observamos um contraste dessas informações em relação ao que nos é mostrado: a personagem parece não ter tido acesso às transformações apresentadas, permanecendo sem lugar para dormir e, aparentemente, desprovida de suas necessidades básicas. Da mesma forma, a reportagem sobre a moda e a sua ampliação reforça algo a que Olive também não tem acesso: o mundo do consumo.

Se compararmos prólogo e newsreel, notaremos que há, no primeiro, uma preocupação em estabelecer a situação americana, ao mesmo tempo em que podemos perceber um posicionamento político e crítico em relação aos aspectos que apresenta, tanto na escolha de quais ressaltar, como no modo como a argumentação a respeito deles é construída. São destacados fatos como o de que Alemanha e Itália, "não ainda inimigas dos Estados Unidos" têm relações comerciais com as corporações americanas. Ao longo do filme, tomaremos conhecimento de que as relações de comércio das corporações americanas com os governos nazista e fascista não se restringem à venda de petróleo, aço e borracha, conforme consta no prólogo, mas também se estendem à compra de obras de arte, como forma de financiamento das atuações dos citados governos. É importante acrescentar ainda que em breve os Estados Unidos estariam de lado oposto à Itália e Alemanha na guerra, porém isso seria apenas politicamente, e não economicamente.

O outro trecho do texto inicial, ao dar notícia da organização dos trabalhadores americanos e da formação de sindicatos, ressalta a ausência de benefícios para esses proletários e ao mesmo tempo destaca a força das greves para lutar por melhores condições de sobrevivência. Por fim, nos é apresentada a resposta do governo para essa situação, uma 
tentativa de inibir o crescimento da luta dos trabalhadores. Portanto, já no prólogo estão cifrados alguns dos principais teoremas que serão desenvolvidos no decorrer do filme: a afinidade dos Estados Unidos com Alemanha e Itália e as conseqüências dela; as condições materiais que impelem os trabalhadores (inclusive os das artes) a se organizarem e confrontarem a realidade que vivem; e, por último, a resposta do governo americano a tais condições materiais: o New Deal, que de certo modo está conectado às outras duas, à medida que apresenta certas semelhanças com algumas das ações dos governos nazi-fascistas e visa conter o impulso contestador na população no momento da crise. Segundo John A. Garraty, as afinidades entre eles são: "um líder forte; uma ideologia que acentua a nação, o povo e a terra; controle estatal da economia e dos assuntos sociais; e, finalmente, a qualidade e quantidade da propaganda governamental" ${ }^{\prime 16}$.

De modo oposto, o newsreel tem uma aparente pretensão de objetividade e busca expor notícias variadas. Conforme já apontamos, destaca a invasão da Etiópia pela Itália de Mussolini; o controle das artes pelo governo nazista de Hitler; Roosevelt e "as conquistas" do New Deal; o mundo do consumo; e, por fim, o entretenimento. Analisando na superfície o conteúdo do noticiário, observamos uma intenção de oposição entre fascismo, nazismo e New Deal, já que aponta o imperialismo do primeiro e a ditadura do segundo, enquanto demonstra a criação de empregos proporcionada pelo governo americano. Entretanto, se atentarmos para o fato de que o newsreel é criação de Tim Robbins, e se o avaliarmos no todo e de forma mais atenta, juntamente com o filme em sua totalidade, perceberemos que a ordem em que são colocadas as notícias, assim como o conteúdo das mesmas, não são aleatórios. Esses fatores colocam em perspectiva as semelhanças entre os três regimes, quando, por exemplo, Hitler fecha a exposição de "arte degenerada" e o governo americano, no final do filme, impede a

\footnotetext{
${ }^{16}$ Garraty, John A. apud Schivelbusch, Wolfgang. Three new deals: reflections on Roosevelt's America, Mussolini's Italy and Hitler's Germany, 1933-1939. New York: Picador, 2006, p. 10.
} 
apresentação da peça The cradle will rock. Outro aspecto que enuncia a possível aproximação entre eles é a estetização da política por parte desses três governos, que se utilizam de mecanismos da indústria cultural, como explicitamos anteriormente.

Durante a projeção do newsreel, podemos perceber uma contradição entre o que é apresentado nele e o que é mostrado da situação de Olive. Essa incongruência se constitui como um procedimento de natureza épica, que insere um comentário na ação. Seu papel é semelhante ao das projeções no teatro de Brecht, possibilitando não apenas inserir a História na ação do filme, mas também introduzir um comentário sobre a ação, já que o narrador do newsreel descreve diversos fatos que influenciam a vida de Olive e dos demais personagens, estejam eles conscientes ou não. O noticiário insere, ao mesmo tempo, certo grau de ironia, quando atentamos ao otimismo estimulado pelo locutor em relação ao breve futuro do país, em oposição à realidade de Olive. A contradição entre o que está sendo descrito e o que é apresentado reforça o conteúdo de ambos e convida o espectador a refletir enquanto assiste ao filme, tendo a possibilidade de estabelecer relações entre o que é dito e o que é visto. Esse jogo de contradições configura uma aposta do cineasta no espectador, que deverá assumir uma postura ativa ao assistir ao filme, buscando ligar os fatos aparentemente desconexos e transformá-los em conhecimento, que possa servir para a reflexão a respeito de sua própria realidade.

O mesmo jogo se adensa na cena subseqüente quando, após ser perseguida por um funcionário, Olive consegue escapar e passa a caminhar pelas ruas de uma espécie de cortiço, enquanto nós ouvimos a música "The clouds will soon roll by", que parece vir do rádio de uma das casas e fala sobre a possibilidade de um amanhã diferente ${ }^{17}$. Enquanto é acompanhada pela câmera, a personagem olha ao seu redor para se certificar de que ninguém

\footnotetext{
17 "Somewhere the sun is shining / so honey don't you cry (...)/ Each little tear and sorrow / Only brings you closer to me / Just wait until tomorrow / What a happy day that will be"
} 
está por perto e em seguida dirige-se a um local mais escuro, levantando o vestido como se fosse urinar.

Na seqüência dessa cena, Olive aborda um homem, vestido com terno, gravata e chapéu e se oferece para cantar uma música por uma moeda, o que ele recusa. Ela segue adiante e, após ter frustrada a tentativa de conseguir dinheiro para comer, passa a cantar um trecho da música que antes tocava no rádio: “em algum lugar o sol está brilhando / então, querida, não chore”. Ela parece ter internalizado a música de forma automática, em mais uma referência à inserção da indústria cultural na vida das pessoas, que passam a repetir cegamente palavras, comportamentos, músicas.

Há uma contradição entre o conteúdo da música, que é aparentemente otimista, e a forma como a atriz canta, como se estivesse sem qualquer perspectiva. Esse contraponto se intensifica na imagem seguinte, em que vemos Olive Stanton passar por um homem e aparentemente se surpreender com o fato dele estar mexendo numa lata de lixo. No entanto, continua cantarolando de maneira quase inaudível o trecho "apenas espere até amanhã", cuja continuação será “Que dia feliz será!”. Nesse momento é ela quem mexe em uma lata, o que cria uma nova e mais intensa contradição entre cena e comentário. Ao cantar a música otimista com uma atitude contrária, de forma automática, revela um aspecto extremamente importante da vida social naquele período: a inserção da indústria cultural da própria forma de expressão das pessoas, que apesar de não se reconhecerem no seu discurso, o produzem de maneira automatizada. Nas palavras de Adorno e Horkheimer,

"O tipo de experiência que personalizava as palavras ligando-as às pessoas que as pronunciavam foi esvaziado, e a pronta apropriação das palavras faz 
com que a linguagem assuma aquela frieza que era própria dela apenas nos cartazes e na parte de anúncios dos jornais." 18

Descrevem, portanto, a alienação do sujeito de sua própria fala, já colonizada pela indústria cultural, que "confere a tudo um ar de semelhança" reconhece no que canta, está alienada de si mesma. Sendo assim, Olive corporifica as contradições do sistema em que está inserida, apesar de não ser capaz de enunciá-las. Por outro lado, o espectador, ao perceber essas contradições e poder relacioná-las com o newsreel e com o prólogo do filme consegue avançar na percepção das relações apagadas pela ideologia, traduzida no espetáculo (o newsreel e o próprio filme) e, assim, constatar os mecanismos que as definem.

Ainda enquanto Olive mexe no lixo, uma voz masculina acompanhada do som de um piano se sobrepõe à dela. A imagem continua sendo de Olive, mas a música é substituída. Ela está se banhando com a água do hidrante na calçada, enquanto continuamos ouvindo a música cantada pela voz masculina. Mais uma vez observamos Olive agir de forma natural, através de atos aparentemente cotidianos e banais, como urinar ou banhar-se, mas que revelam muito a respeito das condições materiais em que se encontra, privada de seus direitos mais primários.

Até esse momento, entretanto, a complexidade do fato de ter sido privada de tais direitos permanece invisível aos olhos de Olive. Do mesmo modo, ao cantar uma música carregada de esperança, sem demonstrar acreditar no “dia feliz que será [amanhã]”, não está atenta para a contradição entre esses elementos. Pelo contrário, ela precisa estar atenta à sua sobrevivência, às ações básicas como calçar os sapatos, urinar, banhar-se, além de se esconder

\footnotetext{
${ }^{18}$ Adorno, Theodor \& Horkheimer, "A Indústria Cultural: O Esclarecimento como Mistificação das Massas". In: Dialética do esclarecimento, http://antivalor.vilabol.uol.com.br, p. 78.

${ }^{19}$ Ibidem, p.78.
} 
para não ser descoberta no local que conseguiu para dormir e tentar fazer algo para conseguir dinheiro para comer.

A questão da relação entre a arte e os espectadores retorna em outra chave na personagem da Condessa La Grange, que é apresentada na seqüência da cena descrita, ocasião em que veste roupas luxuosas, e está acompanhada de seu marido Gray Mathers e seu protegé Carlo. Estão sentados à mesa, bem farta e adornada com prataria e candelabros. Observamos também duas empregadas uniformizadas e um mordomo. As trabalhadoras permanecem paradas, uma de cada lado da porta, como duas estátuas, e são mostradas como equivalentes aos outros objetos que compõem a cena, todos eles reificados. O mordomo serve a Condessa, mas parece ser invisível aos olhos dos patrões.

O casal conversa sobre uma versão de Macbeth representada por atores negros ${ }^{20}$. Gray se espanta com o fato de haver negros nessa representação e pergunta se era um minstrel show, nome dado às performances cômicas em shows de variedades, que se caracterizavam por pessoas brancas que pintavam o rosto para parecerem negras. A Condessa reforça que era Shakespeare e afirma ter sido maravilhosa. Falam sobre a peça por um tempo considerável, e em todo o diálogo assumem uma postura elitista e idealista do que seja a arte. Vêem Shakespeare com as lentes da alta cultura, como representante do cânone literário, e sequer consideram a complexa relação que há em sua obra entre as raízes populares e o mundo da corte, com expressiva referência aos clássicos latinos. Além disso, ignoram a característica mais marcante e progressista dessa representação, que é o fato de ter sido encenada apenas com atores negros e de ser situada no Haiti.

\footnotetext{
${ }^{20}$ Essa montagem de Macbeth realmente aconteceu, tendo sido dirigida por Orson Welles, com financiamento do Federal Theater Project. Para mais informações, cf. Callow, Simon. Orson Welles: the Road to Xanadu. London: J.Cape, 1995.
} 
No momento subseqüente, o mordomo se faz notar, falando "madame" e entregando o jornal nas mãos da Condessa. Seu marido parece interessado em ver o conteúdo do mesmo, e junto com ele lemos "5 mortos, 27 feridos em motim do aço". Quando o mordomo sai do enquadramento, vemos uma janela entre o casal, na qual é possível observar um homem trabalhando. São alternados os personagens em foco, sendo mostrados ora a Condessa, ora seu protegé e, em outros momentos, Gray Mathers. Nesses últimos, são mostrados no mesmo enquadramento o jornal em que está a referida manchete e o trabalhador na janela. Essa representação nos remete a uma cena do filme Cidadão Kane ${ }^{21}$, em que observamos a utilização da profundidade de campo, técnica que permite dar aos diversos elementos que compõem a cena igual nível de importância, e não apenas àqueles que estão em primeiro plano. Em Kane, os pais do menino negociam a custódia de seu filho com o representante de um banco, enquanto observamos ao fundo, através da janela, o garoto brincando e, em seguida, atirando bolas de neve no vidro da janela, como se estivesse aprisionado por aquele acordo comercial, ao mesmo tempo em que luta contra isso. Ao colocar o filme de Orson Welles como referência no filme, Tim Robbins problematiza o próprio reconhecimento da citação pelos espectadores, uma vez que no caso de reconhecerem situarão as analogias que pretende estabelecer e portanto terão intensificada a percepção dessas analogias. Porém, o fato de um número significativo de pessoas não reconhecerem a alusão a Cidadão Kane, tematiza o processo histórico de esquecimento por parte do espectador moderno.

No que concerne à cena de $O$ poder vai dançar, podemos dizer que é necessário levarmos em consideração as ações e os diálogos das personagens em destaque, ao mesmo tempo em que não podemos ignorar esse trabalhador que, assim como a criança no citado

\footnotetext{
${ }^{21}$ Cidadão Kane (Citizen Kane) foi o primeiro longa-metragem dirigido por Orson Welles, em 1941 e está em diversas listas dos melhores filmes de todos os tempos. Apresenta uma série de inovações, sobretudo nas técnicas narrativas e nos enquadramentos cinematográficos. Para saber mais, c.f. Soares, M. O projeto inacabado de Cidadão Kane. In: Crítica cultural materialista. São Paulo: Humanitas, 2008.
} 
filme, encontra-se aprisionado por sua realidade (nesse caso, a exploração do trabalho, ilustrada na notícia). Além disso, podemos associar essa cena àquela em que Olive é espectadora do newsreel. Enquanto naquela cena Olive está em face de uma "janela" que mostra a montagem criada por um cineasta e a vê por detrás; na cena em que a Condessa é introduzida como personagem é inserida uma janela para a realidade, mas ela não percebe. Há ainda um reforço dos aspectos sócio-históricos representados na notícia de jornal, com a qual se surpreende, mas o impulso seguinte é de alívio, ao dizer para o marido "Não foi com você. Ainda bem". Ele muda de assunto, lembrando-a que deverá ir a uma exposição italiana e ela não se opõe a essa mudança, passando então a contar que antes visitará um produtor de teatro para "aprender sobre o processo artístico". Assim como na outra discussão, preferem falar sobre arte de um ponto de vista aurático ${ }^{22}$.

A postura da Condessa a respeito da arte, portanto, a vê desligada de suas determinações históricas, ainda que isso esteja em seu cerne. Mesmo ao conversar com seu marido e protegé a respeito da referida montagem de Macbeth com atores negros, restringe-se a argumentar apenas trivialidades, acerca da impossibilidade de se dizer o nome da peça dentro de um teatro ${ }^{23}$. Além disso, quando falam sobre fatos históricos intimamente ligados à sua vida cotidiana, mudam rapidamente de assunto, limitando-se a discussões superficiais e passando a falar sobre a exposição de arte italiana e o encontro da Condessa com o produtor John Houseman para "aprender sobre o fazer artístico". Uma pergunta que nos vem à mente é: o que ela entende ser o propósito dessa arte sobre a qual pretende aprender?

\footnotetext{
${ }^{22} \mathrm{O}$ termo aurático é usado no sentido definido por Walter Benjamin em seu ensaio "A obra de arte na era de sua reprodutibilidade técnica" a aura da obra de arte "autêntica", definida como "uma figura singular, composta de elementos espaciais e temporais: a aparição única de uma coisa distante, por mais perto que ela esteja". Seu valor é medido por seu caráter único e inacessível. Para Benjamin, esse "modo de ser aurático" tem fundamento teológico, nas formas profanas do culto do Belo e nega tudo que a arte possa ter de político, histórico e social. Fonte: Benjamin, Walter. "A obra de arte na era de sua reprodutibilidade técnica". In: Magia e técnica, arte e política: ensaios sobre literatura e história da cultura. São Paulo: Brasiliense, 1994.

${ }^{23}$ Há uma superstição no meio teatral, principalmente o britânico, de que pronunciar o nome Macbeth dentro (para alguns até mesmo fora) de um teatro traria má sorte. Isso por conta das presenças e invocações malignas que fazem parte da peça. Há também várias histórias sobre eventos ocorridos antes, durante e após a apresentação da peça.
} 
Ela comenta com empolgação sobre a montagem de Macbeth e não apenas contribui para a realização da peça The Cradle Will Rock, em um primeiro momento avisando os atores sobre onde deveriam se encontrar e, em um momento posterior, conseguindo um piano para a encenação, mas também vai ao teatro e vibra com o decorrer dos fatos, celebrando ao lado da equipe do Projeto 891 a realização da peça. Tem, portanto, interesse em uma arte politizada e conseqüente, que pretende discutir aspectos históricos e materiais da sociedade naquele momento. Porém, a relação que estabelece com essa arte é, como já dissemos, aurática. O posicionamento de esquerda parece ser para ela um modismo excitante e divertido, com uma aparência de aventura. E podemos dizer que isso se deve ao fato de que ela não tem em suas vivências uma base material que a identifique com essa perspectiva sobre a arte.

Por outro lado, Olive Stanton não tem como resistir ao aspecto material da arte. Ainda que ela inicialmente não consiga articular reflexões a respeito de elementos históricos presentes na peça, ela vivencia esses elementos, e sua identificação política é fruto de suas experiências, de sentir as conseqüências da História no seu dia-a-dia, conforme desenvolveremos melhor na seção intitulada "História como material".

Um aspecto que torna essa relação ainda mais complexa é o fato de que há um choque entre a caracterização da personagem da Condessa La Grange e a atriz que a interpreta Vanessa Redgrave - visto que, de toda a equipe do filme, ela é a pessoa mais conhecida pela longa história de militância política. Em oposição, sua personagem é uma aristocrata com título de nobreza, que não tem qualquer interesse na revolução, que significaria o fim de todos os seus privilégios, mas ainda assim se envolve e assiste à apresentação da peça, estando junto com os atores no palco na celebração final. Desse modo, o cineasta chama a atenção para o fato de que a arte política é mais complexa do que se imagina e tenta apresentar uma perspectiva livre de ortodoxias. Podemos inclusive dizer que a posição da Condessa se 
assemelha à dos produtores de Hollywood, que vêem os filmes progressistas como mais um gênero, com um público que consome arte política. Tim Robbins então aproveita essa brecha do sistema para expressar suas opiniões. Assim, mesmo que a ajuda seja indireta, inconsciente e que parta de pessoas como a Condessa, ela é necessária para uma ação revolucionária.

Demonstramos portanto, até esse momento, duas relações opostas entre espectadores e a arte, ambas determinadas pelas condições sócio-históricas em que se inserem: a de Olive que, como dissemos, estão intrinsecamente ligadas à experiência que vive e da qual se apropria $^{24}$; e a da Condessa, que configura um apagamento das determinações políticas e sociais da arte. Elas representam apenas duas perspectivas entre outras tantas, uma vez que todos os personagens de $O$ poder vai dançar assumem, em certo momento, a posição de espectador, e assim explicitam uma diferente perspectiva, conforme desenvolveremos no segundo capítulo desta dissertação.

Podemos afirmar que a representação de um mesmo aspecto sob diferentes prismas é uma constante nesse filme, sendo indicadas novas variáveis a cada abordagem, que nos possibilitam retomar a mesma reflexão, partindo de pontos diferentes. Porém todos os personagens desse filme em certo momento assumem a posição de espectador e explicitam uma diferente perspectiva, conforme desenvolveremos no segundo capítulo desta dissertação. $\mathrm{Na}$ cena final podemos testemunhar a intensificação dessa questão, quando atores tornam-se espectadores, e espectadores se integram e assumem um papel essencial na apresentação da peça. Ao atuarem em meio ao público, e na medida em que esse público também participa da representação, eliminam a distinção entre palco e platéia e atuam confiantes em sua própria força.

\footnotetext{
${ }^{24}$ Cf. Benjamin, Walter. "Experiência e pobreza”. Op.cit. para uma compreensão da diferenciação que faz entre experiência e vivência.
} 


\subsection{Artistas como proletários da cultura}

Olive Stanton figura a experiência de um grupo de pessoas, um número incontável de Olives, cuja vivência lhes dá uma perspectiva ainda mais real dos fatos, que se impõem em suas vidas. A partir das experiências é que adquirem consciência das determinantes de sua condição, ou ainda da necessidade de uma atitude para uma possível transformação. O trajeto de Olive ao longo do filme figura, de certo modo, essa conscientização e mudança de perspectiva a respeito dos fatos.

O ponto de partida desse processo de conscientização é a cena em que ela está em busca de emprego, na sede da WPA. Alguns minutos antes, quando estava na fila, ela conversava com um homem que também se encontrava no mesmo local, ambos tentando conseguir um emprego. Ao descobrir que se tratava de um carpinteiro, Olive não o percebe como igual e acredita inclusive que ele esteja na fila errada, já que aquela seria apenas para atores e músicos. Ele se propõe a fazer qualquer coisa, inclusive atuar, colocando todas essas possibilidades como ofícios de igual valor. Ela, pelo contrário, quer um trabalho como artista, acreditando que esse trabalho estaria em um patamar superior ao dos demais trabalhadores, não estando submetido às mesmas relações de mercado. Do mesmo modo que repete a música de forma automatizada, Olive reproduz a idéia de que ser artista a diferenciaria dos demais proletários.

Ao ser atendida no guichê, ela menciona que canta na Broadway. No mesmo momento se corrige, dizendo que cantou na Broadway. A atendente, para saber mais detalhes sobre sua experiência profissional, pergunta o nome do produtor da última peça que 
participou, e ela tenta desconversar, dizendo que ele está morto. A mulher insiste e Olive inventa um nome e diz que a atendente provavelmente nunca teria ouvido falar dele, porém ela responde que pode checar a informação. Então Olive chora, admite que as informações são falsas, e completa "sou apenas uma garota que precisa de uma chance". Conta que está cantando na rua por moedas e precisa de um trabalho. Complementa que canta muito bem e pode trabalhar bastante, mas é desestimulada pela atendente, que diz que o projeto é apenas para os profissionais da área que estão desempregados e que não teria como empregá-la. Todavia, quando Olive está se retirando, aparentemente desapontada, a atendente lhe oferece uma oportunidade de trabalho como contra-regra do Projeto 891.

Nesse pequeno trecho, podemos identificar um contraste entre a ilusão de autonomia dos indivíduos e o fato de eles serem produtos da História de seu tempo, permitindo que os espectadores vejam a realidade com mais clareza. Olive vai desconstruindo aos poucos a visão que tem de si, passando de cantora da Broadway a pedinte, o que a impele a aceitar o emprego que a atendente lhe oferece por fim, como trabalhadora braçal no teatro. Nesse fragmento, podemos ver a representação do que acontece na trajetória dessa personagem ao longo do filme, estando condensadas aqui as situações que ela vivenciará na narrativa como um todo, especialmente na cena final, quando terá papel determinante na resolução do problema que será apresentado às pessoas envolvidas na produção da peça do Projeto 891.

A cena seguinte mostra o personagem Orson Welles conversando com os atores que fazem parte do citado grupo teatral, a respeito de suas condições de trabalho. Eles estão posicionados em um círculo, e Welles está dentro dele. O diretor conversa com os atores enquanto anda sem parar. Eles o observam, e podemos perceber suas reações, já que estão inseridos no enquadramento da câmera durante toda a seqüência. Além disso, também 
interferem e interrompem a fala de Welles, comentando o seu ponto de vista a respeito dos aspectos descritos.

Welles: Se vocês trabalhassem numa mina de carvão ou numa siderúrgica, qualquer trabalho perigoso, eu entenderia a necessidade de intervalos a cada hora. Isto é teatro, não estamos arriscando nossas vidas ou trabalhando com resíduos industriais.

John Adair: O outro lado disso são 20 horas de trabalho, salários baixos e nenhuma proteção.

Canada Lee (para John): Ajudaria se você não interrompesse os ensaios para chamar os intervalos.

Welles: Estamos falando de atores, não operários da indústria têxtil

Dulce Fox: Isso não é o Triangle Fire ${ }^{25}$, é uma peça

Welles: Ninguém está tentando oprimir ninguém. Estamos tentando fazer a peça. Quando a peça estrear nós podemos trabalhar por...

Abe: ...duas horas!

Welles: Moleza!

Frank: Duas horas trabalhando e oito horas procurando outro trabalho

Welles: O que? Frank?

Frank: Nada. Desculpe.

Welles: E a administração vai insistir que trabalhemos oito horas por dia quando estivermos apresentando a peça? É ridículo!

Juntos, os atores constroem um argumento que dá indícios sobre as condições de trabalho dos artistas no período retratado pelo filme, assim como sobre a conscientização desses trabalhadores. Notamos ainda um avanço na luta pela conquista de seus direitos, haja

\footnotetext{
${ }^{25}$ Referência ao incêndio ocorrido na fábrica Triangle Shirtwaist, em 25 de março de 1911, que causou a morte de mais de uma centena de costureiras. Os funcionários dessa fábrica eram em sua maioria mulheres jovens, imigrantes, que trabalhavam 14 horas por dia, em semanas de trabalho de 60-72 horas, costurando vestuário por modestos salários entre 6 e 10 dólares por semana. Esse incêndio contribuiu para a especificação de critérios rigorosos sobre as condições de segurança no trabalho e para o crescimento dos sindicatos que despontavam como consequência da revolução industrial. Fonte: Drehle, Dave Von. Triangle: the fire that changed America. New York: Atlantic Monthly Press, 2003.
} 
vista que há um representante sindical dentro do grupo, John Adair, que faz cumprir uma das conquistas que tiveram até aquele momento - os intervalos. Welles questiona essa posição, ressaltando que não há necessidade de interromper os ensaios, já que o trabalho desempenhado por esses atores não se compara ao de um operário industrial.

Em uma cena anterior, na qual John Adair avisa ser o momento para um intervalo, Welles fica extremamente irritado, dizendo que eles não respeitam o "templo do teatro". Ele acusa John de ser "apenas um trabalhador" e não alguém que acredite na Arte $^{26}$. Utiliza a palavra believer $^{27}$, que também pode ser um termo ligado à religiosidade, que descreve pessoas que têm fé. Segundo Walter Benjaminn" "as mais antigas obras de arte, como sabemos, surgiram a serviço de um ritual, inicialmente mágico, e depois religioso". Conforme apontamos anteriormente, ele afirma que a aura do objeto artístico tem sempre um fundamento teológico. Podemos dizer, então, que o personagem Welles tem, no começo do filme, uma perspectiva aurática sobre a arte e sobre o trabalho do ator, uma vez que visualiza o teatro como uma espécie de religião, como algo sagrado. A conscientização de Welles a respeito do real papel que a arte desempenha surge a partir de suas experiências durante a montagem da peça The Cradle Will Rock, que possibilitam um grande avanço no seu processo de conscientização política e amadurecimento artístico e crítico. Isso porque apesar de o ato de provocar sempre ter sido característico em sua carreira, essa é "a primeira vez que o governo manda guardas armados para impedir a apresentação de uma peça", de acordo com palavras do próprio Welles no filme. Além disso, ele teve contato com diversos atores politicamente engajados e com Marc Blitzstein. Todas essas vivências e pessoas serão determinantes para a carreira do cineasta Orson Welles daquele momento em diante.

\footnotetext{
${ }^{26}$ Utilizamos as palavras arte e artista com letra maiúscula nesse contexto como forma de destacar que a concepção de arte que o citado personagem possui coloca-o em uma posição de superioridade.

27 "You're not a believer. You're a worker"

${ }^{28}$ Benjamin, Walter. "A obra de arte na era de sua reprodutibilidade técnica". Op.cit.
} 
Por outro lado, John Adair é apresentado já inicialmente como possuidor de uma visão clara sobre o trabalho do ator, tendo se engajado na luta sindical como forma de conquista de melhores condições profissionais. É ele quem interrompe os ensaios para os intervalos do sindicato e quem se recusa a participar da peça ao final, após a proibição por parte do sindicato. Isso demonstra que ele tem clareza de que faz parte do projeto 891 para desenvolver um trabalho. Se lembrarmos da oposição que Karl Marx faz entre trabalho livre e alienado, poderíamos dizer que originalmente o trabalho artístico seria o modelo do trabalho não-alienado, por meio do qual o sujeito expressa suas idéias, de forma livre. Em um momento posterior, o próprio Marx afirma que a arte também pode se tornar uma objetivação alienada, por estar inserida na lógica do sistema capitalista. A presença do personagem John Adair, assim como toda a cena descrita, aponta para uma intenção de explicitar não apenas que o artista é um trabalhador, mas principalmente que é um trabalhador em muitos casos alienado do produto de seu trabalho. Nesses casos, a dimensão de expressão de idéias, de intervenção social por meio da arte, é perdida.

Podemos dizer que, da mesma forma que acontece ao longo do filme em relação a outros aspectos, é possível tomarmos essa questão, da conscientização pelo artista de sua condição de trabalhador, como ponto de partida, e identificar no filme um mapeamento de diversos posicionamentos.

Marc Blitzstein, por exemplo, é mostrado desde o primeiro momento como um trabalhador. Na cena em que ele está no seu apartamento, há um grande esforço em caracterizar o processo de escrever e compor a música. Busca-se reforçar que a composição da obra por parte do artista é resultado de bastante trabalho, de dedicação de tempo e de energia, e não de um momento iluminado de inspiração. Posteriormente, nos é mostrada a apresentação que Marc faz para Hallie Flanagan e os produtores do Projeto 891, na tentativa 
de conseguir financiamento para realização da peça. Blitzstein é plenamente consciente de sua condição de trabalhador, conforme explicita em sua conversa com Welles, quando questiona o diretor a respeito de onde estaria o limite entre receber financiamento para a concretização de seus projetos artísticos e a prostituição. Mais do que isso, a própria peça que compõe coloca em questão todos esses aspectos e provoca uma reflexão a respeito disso.

Olive, conforme vimos, busca inicialmente ser uma artista, acreditando que isso a tornaria diferente dos demais trabalhadores. Entretanto, por conta de suas vivências, passa por um processo de conscientização e amadurecimento político, que são frutos de uma reflexão baseada nas condições materiais. Ou seja, tais processos são determinados pelas condições sócio-históricas, que a permitem perceber que é uma proletária como os demais.

De forma semelhante, Aldo Silvano, um dos atores do projeto, discute com seus familiares sobre a natureza diferenciada de seu trabalho, destacando que "você não espera em filas para conseguir um emprego no teatro. Você participa de audições, de testes. Você lê, finge ser o personagem. Você não pega fila". Entretanto, a cena descrita anteriormente, que mostra Olive na fila de artistas e outros trabalhadores buscando um emprego na WPA, contraria o argumento de Aldo e expõe sua visão idealizada em relação à profissão. No final do filme, durante a passeata de artistas e público em direção ao teatro onde será apresentada a peça The cradle will rock, Aldo explica para os filhos que não fará a peça, "porque o governo diz que não posso (...) eles são meus patrões, que pagam meu salário, e estão dizendo que não posso fazer a peça". Diante da insistência de seus filhos para participar, responde: "eu não posso. Foi proibido. E eu poderia perder meu emprego". Nesse momento, já se deu conta de que seu trabalho não tem diferenciação em relação aos outros, sendo principalmente um meio de sobrevivência. Apesar disso, decide participar da peça, sendo fatores determinantes para tal 
decisão a conscientização de seu papel de proletário da cultura e sua intenção de atuação política.

Os demais atores da peça agem de forma semelhante. Entretanto, eles parecem estar conscientes do fato de serem trabalhadores desde o início do filme, uma vez que são sindicalizados e exercem seus direitos. Ao mesmo tempo, demonstram certo envolvimento com o trabalho e com os ideais representados na peça, a ponto de arriscarem seu futuro profissional para contarem essa história que julgam importante ser contada.

Conforme explicitamos anteriormente, John Adair também está consciente do fato de que é um trabalhador. Porém, explicita outro ponto de vista sobre essa questão, por encontrarse em outro estágio, de alienação em relação ao trabalho que realiza. Não tem qualquer idealização de que fazer a peça seria um ato revolucionário. Pensa de forma prática, negandose a participar por conta da proibição do sindicato, sem questionar as razões que o levaram a essa atitude.

Há ainda muitos outros artistas presentes no filme, que representam pontos de vista diferenciados a respeito do teorema que argumenta que o artista é um trabalhador. Pretendemos realizar uma análise mais aprofundada desse aspecto no segundo capítulo desta dissertação. Nele será feita uma reflexão a respeito do modo como o financiamento que recebem para sua arte representa ao mesmo tempo possibilidades e limites, relacionando esse aspecto com o grau de conscientização de artistas como Rivera, Crickshaw, entre outros.

O que se deve ter sempre em mente é que, mais do que reconhecer o artista como um proletário da cultura, é necessário avançar em relação ao que esse reconhecimento permite: incentivar o artista (e o mesmo vale para o intelectual) a assumir uma posição no processo produtivo, ao lado do proletariado. Acreditamos que Tim Robbins é um dos exemplos desse 
tipo de artista, uma vez que privilegia na montagem do filme aspectos do mundo do trabalho e, mesmo tempo, marca fortemente sua posição política progressista. Sendo assim, realiza na prática o que Walter Benjamin teorizara: uma refuncionalização de formas e técnicas por uma inteligência progressista, interessada na liberação dos meios de produção a serviço da luta de $\operatorname{classes}^{29}$.

${ }^{29}$ Cf. Benjamin, Walter. "O autor como produtor". Op.cit. 


\subsection{História como material}

A seqüência final da narrativa que conta a montagem de The cradle will rock começa no teatro em que a referida peça será apresentada; vemos a imagem de um grupo de pessoas arrancando uma bandeira fascista que estava pendurada na parede. A platéia é mostrada em plano geral, por meio do qual podemos ver sua celebração desse ato. Vemos então um plano médio da família de Aldo Silvano, e um de seus filhos pergunta o porquê de as pessoas estarem agindo daquela forma. Aldo responde que ele deveria perguntar ao seu tio, já que aquela é a bandeira dele, em menção a um episódio apresentado anteriormente no filme, no qual há uma discussão familiar quando Aldo vê seus fillhos cantando músicas fascistas, ensinadas pelo tio, e é expulso da própria casa pelo pai, que custeava a sobrevivência da família.

Há um corte e vemos outro plano geral da platéia, no qual podemos perceber Olive chegando ao teatro. Em seguida, Dulce, uma das atrizes da peça, é mostrada em plano médio, sentada entre outras pessoas. É interessante destacar que durante a cena há figurantes se movimentando nas fileiras do teatro, inclusive passando na frente das personagens. Essa configuração é intencional: em um filme que seguisse o padrão clássico de filmagem, tal movimentação à frente das personagens conhecidas representaria apenas uma distração ao espectador, sendo normalmente descartadas. Nesse filme, os indivíduos não fazem parte de um mundo autônomo, que funciona de modo a permitir que atuem. Eles estão inseridos em um ambiente, em um momento histórico específico, e fazem parte de um grupo de pessoas que podem ou não ser nomeadas ao longo da narrativa. 
Vemos Olive Stanton em meio às pessoas que entram no teatro e ouvimos a voz de Dulce, chamando-a. Olive conta que John cumpriu sua promessa, expulsando-a de casa por conta de seu desejo de estar presente na apresentação de estréia da peça, e pede para dormir no chão de Dulce. As atrizes são mostradas em plano geral novamente, em meio às pessoas que estão no teatro para assistirem à peça. Há um corte para a cena do baile de máscaras, cujo conteúdo será explorado no segundo capítulo desta dissertação. Voltando ao teatro, Welles entra no palco e é recebido com aplausos da platéia:

Senhoras e senhores, sejam bem vindos à primeira produção desertora do Federal Theatre. Creio que já estejam informados das circunstâncias que nos trouxeram a esse teatro empoeirado nessa bela noite de verão. Algo nessa peça está assustando o pessoal de Washington. Deve haver alguma força sinistra atuando nessa peça. [dá uma risada sinistra, ao que a platéia ri] Então, sem mais reclamações, permitam-me apresentar "o monstro" por trás de The cradle will rock, Sr. Marc Blitzstein.

Blitzstein entra no palco, agradece os aplausos e senta ao piano, já iniciando a descrição das rubricas da peça, que apresentam o local onde ela se passa: Steeltown, Estados Unidos. De acordo com as palavras do próprio Marc Blitzstein,

“e lá estava eu, sozinho em um palco vazio, sentado ao piano descoberto, vestido com mangas curtas. Eu mesmo, produzido por Houseman, dirigido por Welles, iluminado pro Feder e conduzido por Lehman Engel.” Blitzstein não sabia quantos atores tinham decidido ir ao teatro e onde eles estavam na platéia, mas ele começou "pronto para fazer tudo sozinho. Eu comecei cantando a primeira música de Moll e ouvi as palavras serem tomadas de 
minha boca pela própria Moll, sentada do lado direito; o talentoso Feder instantaneamente mudou o foco de luz para ela." ${ }^{30}$

Voltando ao filme, o personagem do dramaturgo diz: "Uma prostituta anda pela rua e pára embaixo de um poste. Esta é Moll”. Ele começa a cantar. A música que ouvimos é A nickel under the foot, a mesma que ele estava compondo na seqüência inicial do filme, quando seguíamos os passos de Olive Stanton, após ser expulsa do teatro e ter o seu pedido de cantar uma música em troca de uma moeda (a nickel) negado. Naquele momento, conforme descrito, a Olive estava se banhando com a água do hidrante na calçada. A câmera se afasta dela, e por meio de um movimento de grua mostra-a por cima, ainda se banhando. Sobe, sem corte na seqüência, em direção a uma das janelas do edifício em frente à calçada onde Olive se encontra, entra pela janela, como se estivesse afastando as cortinas e mostra Marc Blitzstein ao piano cantando e, mais que isso, compondo a referida música. Ele sequer conhece Olive Stanton, mas conhece as outras Olives, aquelas cuja experiência é tipificada nessa personagem, que não é representação de um indivíduo, mas sim a figuração de seres sociais e experiências coletivas.

Continuando a descrição da cena no teatro, Marc ainda canta a mesma música. Vemos imagens de Olive e Dulce, em meio à platéia, assim como de John Adair chegando ao teatro, e de Sandra, outra atriz do Projeto 891, aparentemente muito desapontada. Nesse momento, ouvimos a voz de Olive, cantando junto com Marc, enquanto assistimos às reações do público e atores que passam a procurar a origem da voz, impressionados. A câmera mostra Olive se levantando, ao mesmo tempo em que observamos mais pessoas surpresas ao seu redor. Marc pára de cantar e ela continua cantando, sozinha, sendo então iluminada por um dos refletores.

\footnotetext{
${ }^{30}$ Blitzstein, Marc apud Quinn, Susan. Furious improvisation: how the WPA and a cast of thousands made high art out of desperate times. New York: Walker Publishing Company, 2008, p. 181.
} 
Observamos então alguns dos atores, o produtor e o diretor da peça e, em seguida, Olive começa a se movimentar, saindo do local onde se encontra. Caminha em direção ao palco olhando assustada para as pessoas, e termina de cantar a canção. Essa música, como dissemos, se chama Nickel under the foot. Apresenta um episódio em que Moll, uma prostituta hesitante, está faminta e sente uma moeda embaixo de seu pé, que era na verdade fruto de sua imaginação, devido à fome. A letra conta que ela não está em Steeltown há muito tempo e trabalha apenas dois dias por semana, já que nos outros dias seus serviços não são necessários. Ela recebe apenas dois dólares quando trabalha. Parece ouvir alguém dizer "vamos comer?", mas não sabe de onde veio a voz. Segundo descreve Blitzstein,

\begin{abstract}
Ela conta a história de uma noite, quando Moll estava sem esperanças de se alimentar e então ela viu o que parecia uma moeda no chão. "eu lhe digo, cavalheiro, você não imagina qual foi a sensação de imaginar que havia uma moeda embaixo de meu pé”, ela diz. Ter aquela moeda significa toda a diferença entre felicidade e desespero, bem e mal. "Cada sonho e projeto dependendo de você manter ou não aquela moeda embaixo de seu pé"
\end{abstract}

Em ambos os casos, de Olive Stanton e da personagem que ela interpreta na peça, há uma referência à moeda de cinco centavos (nickel). Nickel também remete à origem da própria peça, que surge a partir de uma conversa entre seu autor, Marc Blitzstein, e Bertolt Brecht. Nessa conversa, Marc apresenta a música Nickel under the foot e Brecht sugere que amplie a canção e trate não apenas das pessoas que estão passando fome, por necessidade, mas também das outras formas de prostituição: da imprensa, da Igreja, das Cortes, dos artistas, entre outros. É importante destacar que essa conversa é reproduzida no filme, quando

\footnotetext{
31 Ibidem, p.165.
} 
o espectro de Brecht faz menção à necessidade de Marc referir-se à prostituição nas mansões, universidades e sindicatos.

A própria realidade surge no filme, então, como matéria histórica para a constituição das narrativas a serem contadas. Tomando Olive Stanton como exemplo, notamos que ela vivencia na realidade a experiência que será representada na peça. Desde o início do filme, há momentos em que a câmera abandona a figuração do coletivo para seguir uma só personagem. Aparentemente, ela estaria deixando de representar a História para apresentar um indivíduo mas, na verdade, a câmera está demonstrando de que modo essa personagem se constitui como um tipo, que representa uma coletividade, visto que aglutina características gerais que remetem ao coletivo. É de pessoas como Olive que surge o material para a composição da peça The Cradle Will Rock, conforme é explicitado inclusive cenicamente. Por intermédio do movimento da câmera, que parte do enquadramento dessa personagem e se afasta aos poucos, em uma seqüência sem cortes, terminando nas páginas das partituras de Marc Blitzstein.

É interessante atentar para o fato de que Olive decide, no calor do momento, atuar na peça, impulsionada pela própria História, que invade o teatro e a vida de cada um dos que lá estão presentes. Sua atitude inspira os demais atores e músicos que, fazendo parte dessa experiência, também são incitados por suas vivências a atuarem na peça. Nas palavras do compositor Marc Blitzstein,

Começou uma espécie de partida de tênis de um ator a outro, enquanto Feder captava quantos deles conseguisse com seu holofote, e conversas musicais aconteciam por todo o teatro. O elenco tinha 
estudado tão completamente que eles poderiam atuar dormindo... tudo aconteceu extraordinariamente sob este controle brutal. ${ }^{32}$

Essa é uma das principais teses do filme, que coloca a História como protagonista, a fim de mostrar como os elementos históricos foram essenciais para que todos os eventos retratados no filme ocorressem. Busca demonstrar, assim, que "não é a consciência que determina a vida, mas sim a vida que determina a consciência.. ${ }^{, 33}$ Ou seja, a realidade é

um produto histórico, o resultado da atividade de toda uma série de gerações, cada uma das quais ultrapassava a precedente, aperfeiçoando a sua indústria e o seu comércio, e modificava o seu regime social em função da modificação das necessidades. ${ }^{34}$

Para além do filme também podemos perceber de que maneira os fatos históricos serviram como combustível para um despertar político de várias camadas da população americana que sofriam as conseqüências da Grande Depressão. "O surgimento da União Soviética como uma potência industrial mundial e um promissor 'paraíso dos trabalhadores' proporcionou um crível, embora ilusório, modelo alternativo para os americanos economicamente desprivilegiados" ${ }^{35}$. De acordo com informações do livro Cradle Will Rock: the movie and the moment, a jornalista Lorena Hicrock, contratada pelo governo no período,

\footnotetext{
32 Ibidem, p.181.

${ }^{33}$ Marx, Karl. A ideologia alemã.

${ }^{34}$ Ibidem. p. 11

${ }^{35}$ Robbins, T. op.cit. p. 11
} 
afirmou que, naquele período, “grande número de desempregados estão 'no limite' - não seria necessário muito esforço para transformá-los em Comunistas"36.

Michael Denning, em seu livro The Cultural Front ${ }^{37}$, ressalta que, enquanto o ano de 1929 tornou-se símbolo de desespero e ruína, emblema da queda da economia e do fim de uma forma de vida que se estabelecera até aquele momento, o ano de 1934 surgiu como um dos momentos líricos da história americana. Foi possível conhecer a força, a militância e a solidariedade dos trabalhadores americanos. Howard Zinn ${ }^{38}$ conta que há diversos relatos de organização popular espontânea nesse período. Antes de Roosevelt assumir a presidência, as pessoas não esperavam que o governo as ajudasse; elas se organizavam para atos de ajuda mútua, por via de ação direta para conseguir comida em estabelecimentos comerciais, evitar despejos e organizar trabalhadores. Essa transformação na atitude e na visão de mundo acontecia também no âmbito da cultura, essencialmente formada por artistas e intelectuais vindos da classe trabalhadora. Em suma, as condições históricas e sócio-econômicas do período possibilitaram uma mudança na visão de mundo da população, assim como uma disponibilidade para ouvir discursos diversos e uma ampliação do espírito de coletividade. E, ao contrário de filmes clássicos hollywoodianos, em que há um apagamento das relações históricas, vemos em $O$ poder vai dançar essas relações serem fortemente representadas e destacadas.

Por volta dos dezenove minutos de filme, Marc Blitzstein está em um parque, onde há uma manifestação em andamento. Primeiramente, observamos Marc chegando, enquanto um líder sindical discursa a respeito da ligação entre a indústria e o governo, fazendo referência à repressão de manifestações dos trabalhadores por policiais. Em certo momento, surge a figura

\footnotetext{
${ }^{36}$ Ibidem, p. 11

${ }^{37}$ Denning, Michael. The cultural front: the laboring of American Culture in the twentieth century. New York: Verso, 1998

${ }^{38}$ Zinn, Howard. Op.cit.
} 
de Brecht, que conversa com Blitzstein a respeito da peça e sobre a necessidade de abordar as várias formas de prostituição, conforme expusemos anteriormente. A continuação não é apresentada logo em seguida na montagem. Há uma interrupção, na qual assistimos cenas de outras narrativas, que apontam outros pontos de vista sobre os mesmos teoremas e, depois, voltamos à continuação dessa cena.

Essa passagem de uma narrativa para outra acontece diversas vezes ao longo de todo o filme, que avança por meio de interrupções e saltos. A montagem e os cortes não seguem um padrão, alternando-se tanto a velocidade quanto a forma como são feitas as passagens. Em vários momentos há uma ponte sonora entre uma cena e outra, por meio da voz de uma personagem que permanece da cena anterior ou se antecipa da seguinte ou, ainda, por intermédio de uma música que faz o mesmo, "invadindo" a cena anterior ou posterior àquela que pertence. Em outros momentos, o assunto tratado em uma narrativa é relacionado ao que personagens pertencentes à outra também comentam. Todavia, a maioria das passagens entre narrativas é feita sem gancho ou relação explícita. Há cortes bruscos, e esses permitem um efeito de distanciamento, de estranhamento em relação ao que observamos. Distanciar é, segundo Brecht, ver algo em termos históricos.

A passagem dessas duas cenas ocorre da mesma forma, sendo dadas sugestões dos teoremas que o cineasta propõe. Na continuação da cena que nos referimos anteriormente, Marc se dirige a um dos bancos do parque, senta e começa a tocar piano no ar. Ouvimos o som do piano inexistente e ele começa a cantar "Ouça, aqui está uma história. Sem muita diversão e sem muita exaltação". A seguir aparece um piano, e ele continua tocando como se nada tivesse se alterado. "Classes pobres, rebaixem-se". Então ouvimos uma voz feminina, mas não nos é mostrada a imagem de ninguém cantando. Ela canta junto com ele "aquilo que você nunca se importa em ver até que se revele". Vemos agora imagens da polícia chegando 
ao protesto. Agora só a voz feminina canta "Uma grande questão grita dentro de mim: Quantos impostores / empreendedores da paz / fura-greves contratados / Quantos exaustos, doentes, morrendo? Quantos corpos empilhados serão necessários para que você perceba o que está acontecendo?”. Enquanto ela canta nos são mostradas imagens do conflito entre polícia e manifestantes. Esses correm e passam por Marc, que permanece tocando o piano, apesar de não vermos suas mãos. No momento seguinte Blitzstein é mostrado de outro ponto, e agora o vemos novamente fazendo os movimentos de quem toca um piano, mas no ar. A câmera faz um movimento lateral até filmá-lo de frente. A música termina, e atrás dele estão duas pessoas: um homem de terno e uma mulher vestida de noiva, que em outro momento tínhamos reconhecido como sendo sua esposa. Este homem que está atrás de Marc tem semelhanças físicas com Brecht e fala com sotaque alemão "Está muito séria”. O fantasma de sua mulher diz “Onde está a ironia? Onde está o humor?", e Brecht diz "E as outras prostitutas?". A imagem agora é de alguns policiais e manifestantes, enquanto ouvimos Marc gritando "vocês são prostitutas". Ouvimos então uma música diferente, que não tem relação com esta cena, mas com a próxima, pertencente à outra narrativa. Marc continua "vocês são prostitutas do Estado. Os policiais são prostitutas”. Logo após fazer essa afirmação, ele leva uma pancada de um dos policiais.

Percebemos na cena em que Marc chega ao parque, assim como naquela descrita anteriormente em detalhes, uma justaposição de diversos elementos: na primeira, vemos a manifestação, a fala do líder sindical, a conversa de Marc com Brecht; na segunda, vemos Marc tocando o piano (que ora pode ser visto, ora desaparece), a entrada dos policiais e a repressão da manifestação, além da aparição de Brecht novamente e da esposa de Marc. Esses itens causam um certo estranhamento na percepção, devido ao fato de não sabermos se a cena em que estão os policiais faz parte da imaginação de Blitzstein ou se é realidade. Na verdade, ela é um pouco de cada, pois representa a realidade sendo incorporada à arte. $\mathrm{O}$ 
efeito de estranhamento é utilizado em vários níveis: na forma, na caracterização dos personagens e na composição de cena e planos, na utilização da música, assim como nos movimentos de câmera, que reforçam tal efeito e o deixam bem marcado.

Sendo assim, utilizar no filme a já referida estrutura de narrativas em rede, combinada com esses vários mecanismos de estranhamento, possibilita uma constante interrupção na sucessão de ações. Tais interrupções contribuem ainda mais para o despertar de uma reflexão por parte do espectador em relação ao filme a que assiste, já que impedem em diversos momentos uma ilusão por parte do público. Tal ilusão se oporia aos objetivos de uma forma artística que pretendesse tratar os elementos do real no sentido de uma série de experiências. Porém, de acordo com Walter Benjamin, é no fim e não no princípio desta experiência que se encontram as situações. E essa forma utilizada pelo teatro épico (e de certa forma também pelo filme $O$ poder vai dançar) não objetiva aproximar essas situações do espectador, mas sim distanciá-las dele. Dessa forma, ele as reconhece não com presunção, como no teatro do naturalismo, mas com espanto. Assim como o teatro épico, esse filme não reproduz as condições, ele as descobre. Não há uma reprodução de uma fatia da realidade, mas uma exposição dos elementos que a compõem. De acordo com Benjamin,

a descoberta das condições se efetua por meio da interrupção das seqüências. Mas a interrupção não se destina a provocar uma excitação, e sim a exercer uma função organizadora. Ela imobiliza os acontecimentos e com isso obriga o espectador a tomar uma posição quanto à ação, e o ator, a tomar uma posição quanto ao seu papel enquanto artista. ${ }^{39}$

\footnotetext{
${ }^{39}$ Benjamín, Walter. “O autor como produtor”. Op.cit., p. 133
} 
Os personagens presentes no filme também assumem lados e tomam uma posição frente aos fatos que vivenciam. Não há representações "objetivas" ou personagens "neutros". A politização não se coloca como uma opção individual, mas sim como decorrência das condições históricas. Portanto, todos tomam posições que determinam suas ações. Segundo Walter Benjamin, "Tretiakov distingue entre o escritor operativo e o informativo. A missão do primeiro não é relatar, mas combater, não ser espectador, mas participante."^40

Tomando como ponto de partida os elementos analisados no filme, poderíamos então afirmar que o cineasta Tim Robbins se assemelha ao escritor operativo, posicionando-se ao lado do proletariado também na qualidade de produtor?

Ele não apenas marca fortemente sua posição política, mas utiliza-se de diversos mecanismos formais que permitem "a superação do contraste infecundo entre forma e conteúdo"41. Propõe um mapeamento das ideologias às quais os artistas aderem, de formas artísticas, eventos históricos, limites e avanços do período que retrata. Além disso, o cineasta estrutura o filme de modo a incitar uma postura ativa por parte dos espectadores, que são colocados face aos eventos históricos, e têm acesso a elementos para reflexão, análise, e conseqüente posicionamento político na luta de classes.

O poder vai dançar é determinado pelas condições sócio-históricas e políticas que o cercam, uma vez que foram elas que motivaram a escolha tanto do conteúdo quanto da forma. O filme é definido em seu princípio como "uma história (predominantemente) verdadeira" ${ }^{42}$. Ele é uma combinação de personagens reais e fictícias, para contar fatos reais na ficção, o que enriquece a obra e traz novas possibilidades de abordagem e análise.

\footnotetext{
${ }^{40}$ Ibidem, p. 123

${ }^{41}$ Ibidem, p. 122

42 " A (mostly) true story"
} 
Conforme afirma Tim Robbins no livro em que faz um rápido panorama daquele momento histórico e de alguns aspectos da produção do filme,

No início de Cradle Will Rock, uma frase aparece: "Uma história (predominantemente) verdadeira". Isso é um filme, e pelo interesse da narrativa eu mudei alguns fatos e manipulei algumas datas. A controvérsia entre Rivera e Rockefeller na verdade ocorreu em 1932, a invasão da Etiópia em 1935, a queda do Federal Theatre em 1939. Eu inventei os personagens de Mathers, Condessa LaGrange, Carlo, Aldo Silvano, Tommy Crickshaw e seus pupilos, Sid e Larry. O resto dos personagens desse filme são baseados em pessoas reais e são tão historicamente precisos quanto possível.

Os retratos de Orson Welles e John Houseman são baseados em relatos de pessoas que os conheceram na época, e eu tentei trazer seus gênios precoces à vida sem romantizá-los demais. Se Margherita Sarfatti realmente vendeu arte clássica para a elite dos Estados Unidos não se pode saber ao certo, mas nós sabemos que ela era uma firme defensora do Fascismo e uma ativa propagandista de Mussolini. Nós podemos nunca saber a verdade completa sobre onde foi parar a arte confiscada após a Segunda Guerra Mundial, mas nós sabemos, por meio de recentes processos judiciais, que muitas dessas obras estão agora em coleções privadas.

Do mesmo modo, eu tentei retratar Nelson Rockefeller e William Randolph Hearst corretamente, apesar de alumas de suas ações no filme representarem saltos metafóricos. Não há como saber exatamente o que acontece nos bastidores do poder - pode-se apenas tomar os fatos deploráveis (o apoio de Hearst a Mussolini e Hitler, a destruição do mural de Rivera por Rockefeller) e preencher o resto com imaginação. ${ }^{43}$

\footnotetext{
${ }^{43}$ Robbins \& Burns. Op.cit., p. 133.
} 
O cineasta condensa no tempo do filme diversos eventos históricos que aconteceram na década de 1930 (não necessariamente no outono de 1936), ligando a eles fatos fíctícios. Do mesmo modo, entre os personagens, observamos uma série de figuras reais, misturadas a outras tantas personagens fictícias. O fator determinante para essas escolhas não é o grau de veracidade que poderiam estabelecer, mas sim as proposições levantadas pelo filme. Além disso, combina esses eventos, personagens e as obras artísticas para, desse modo, dialogar com o que estes têm em comum e de diferente, o que possibilita uma perspectiva analítica diferenciada dos fatos que ocorriam concomitantemente e dos aspectos indicados no filme.

Há, portanto, por parte de Robbins, uma busca pelo resgate do momento histórico em que surgem tais eventos, apontando para uma possibilidade de colocar os fatos dentro de um contexto e estabelecer relações, reconstruindo a memória do referido período. Mais do que isso, busca utilizar essa memória como fonte de inspiração para as massas no momento em que faz o filme, como procuraremos argumentar ao longo da conclusão desta dissertação.

Antes do prosseguirmos, convém uma retomada dos aspectos ressaltados ao longo deste capítulo. Buscamos, a partir da descrição e análise de algumas cenas do filme $O$ poder vai dançar, demonstrar como ele, já desde o princípio, toma como base uma tradição épica que, ao invés de vivências, apresenta concepções de mundo. A seqüência das ações não se dá de forma linear, mas por meio de saltos e interrupções, uma vez que a tensão não visa um desfecho, mas sim o desenvolvimento. A História é colocada como protagonista, as personagens, como seres em processo, e os espectadores são incentivados a assumirem uma postura ativa: estabelecer relações, refletir sobre os elementos expostos e analisar as situações, por intermédio de uma rica combinação de elementos de forma e conteúdo. Além disso, apontamos para uma oposição a qualquer postura aurática por parte do público e dos artistas, o que ainda retomaremos com mais detalhe. Outra perspectiva que buscamos destacar é a da 
realidade de trabalho de alguns dos artistas do filme e seu grau de conscientização de sua condição de proletário da cultura, assim como as implicações que esse aspecto traz para as relações entre as personagens e ações que essas praticam.

Por fim, trouxemos à discussão de que maneira a matéria histórica se faz presente na narrativa do filme, funcionando como princípio organizador das cenas. Isso porque observamos em diversas cenas a apresentação de algum fato que em um momento posterior é incorporado a alguma das obras artísticas representadas no filme. Como exemplo, citamos a cena no parque, que em outra ocasião é retomada pela peça The Cradle Will Rock. Da mesma forma, as conversas "entre o ventríloquo Crickshaw e seu boneco" são retomadas no ato final do artista de vaudeville. Assim também ocorre no filme como um todo, que incorpora aspectos das formas artísticas e período histórico que representa e os torna parte da própria estrutura fílmica, narrativa e formal. De modo complementar, constrói personagens atuantes, que vivenciam processos ao longo do filme e, por isso, estão diferentes e com uma visão de mundo diferente ao final de sua jornada. O diretor sinaliza a possibilidade de alguém como Olive Stanton ser protagonista de sua própria História, haja vista que ela é ao mesmo tempo quem inspira o conteúdo da peça e quem atua no papel principal, representando fatos e experiências que fazem parte de sua própria realidade.

Em seguida procuraremos desenvolver alguns dos aspectos já apontados, sob outra perspectiva, de modo a analisar os limites e possibilidades apresentados pelo cineasta em cada uma das narrativas e formas artísticas presentes no filme. Dessa maneira, analisaremos as relações de produção das artes na década de 1930 nos Estados Unidos, assim como as formas de financiamento a que elas se submetiam, e as conseqüências de ambos. Refletiremos a respeito dos personagens-artistas e da postura que assumem dentro do contexto em que se inserem. Por fim, levando em conta que o filme foi realizado na década de 1990, buscaremos 
analisar o posicionamento do cineasta Tim Robbins em relação aos elementos apontados, de modo a refletir a respeito da importância deste filme não apenas no seu período de produção, mas ainda hoje. 


\section{Arte: avanços e limites}

Ao sair do Rockefeller Center, Margherita Sarfatti encontra com Diego Rivera, que reclama a respeito do fato de ter sido expulso do prédio:

Diego: Seu amigo Rockefeller me pôs pra fora.

Margherita: Lênin no lobby de um capitalista. O que você estava esperando?

Diego: eu fui tratado como um criminoso comum.

Margherita: Você foi contratado pra fazer um trabalho. Agora seu patrão não gosta do que você fez. Se você quer pintar sua revolução, faça isso às suas próprias custas. Vá pintar um mural por nada na Liga dos Jovens Comunistas.

Diego: Porque eu aceito o dinheiro do Rockefeller agora sou escravo dele?

Margherita: Sim!

Diego: Oh! Quando você parou de apoiar os artistas?

Margherita: Eu apóio sua arte, mas isso não significa que eu deva apoiar sua revolução.

Diego: É a mesma coisa!

Margherita: Não é!

Diego: Que mentira você vive! Uma judia fascista!

Margherita: E você, um rico comunista!

Nesse diálogo, vemos representadas duas posições opostas em relação à arte, uma que concebe o interesse de engajamento político, não importando em que local ou condições isso ocorra; outra, que considera o trabalho artístico apartado da arte como expressão de idéias. Ambas concepções estão, de certo modo, equivocadas, pois a primeira desconsidera a situação do artista enquanto trabalhador e a segunda, apesar de reconhecer esse aspecto, não acredita que possa haver possibilidade de militância dentro do contexto de trabalho do artista, 
caracterizando o trabalho como alienado. Em $O$ autor como produtor ${ }^{44}$, Benjamim discorre sobre a necessidade de reconhecermos o intelectual como um produtor, que deve assumir uma posição no processo produtivo, ao lado do proletariado. Sendo assim, propõe uma refuncionalização de formas e técnicas por uma inteligência progressista, interessada na liberação dos meios de produção a serviço da luta de classes. Ou seja, há que se dar um passo adiante na identificação do artista como trabalhador e reverter isso em uma ação de transformação social.

Por se reconhecer como trabalhador, Tim Robbins privilegia na montagem do filme aspectos do mundo do trabalho. Todos os personagens assumem posições em relação a esse mundo e às concepções de arte, ou seja, se posicionam no debate das forças produtivas.

A posição do cineasta é progressista e positiva, pois acredita que ainda há possibilidade de ação, e realiza uma espécie de mapeamento de posições e meios de ação diversos. Buscaremos, ao longo deste capítulo, pontuar os elementos do referido mapeamento feito pelo cineasta e avançar na proposição de que Tim Robbins teria a intenção de estruturar uma espécie de equação, em que ele apresenta inúmeras variáveis de cada um dos teoremas que propõe, conforme apresentado no primeiro capítulo. Realizaremos então uma análise detalhada das formas artísticas representadas no filme, assim como dos artistas e das relações de produção em que se inserem. É interessante destacar que há uma recusa por parte do cineasta de qualquer espécie de aposta acrítica e inocente. Sendo assim, ele demonstra potencialidades e limites pertinentes aos citados aspectos. Esse princípio aparece de forma localizada, por exemplo, quando trata de personagens como o pintor revolucionário Diego Rivera, que aceita pintar um mural no lobby do Rockefeller Center; e, ao mesmo tempo, como princípio estrutural do filme, em termos de sua forma e conteúdo. Podemos citar a cena final,

\footnotetext{
${ }^{44}$ Benjamin, Walter. O autor como produtor. Op.cit.
} 
na qual há um momento de celebração, interno ao teatro, mas a montagem nos possibilita colocar esse fato em perspectiva, à medida que ocorre simultaneamente ao cortejo fúnebre do Federal Theatre, que termina na Broadway, no momento presente.

Apresentaremos os aspectos indicados por meio de sub-capítulos que trarão separadamente diversas formas de arte e os aspectos relacionados a elas, além daqueles que as realizam. Consideraremos o vaudeville e o artista que o representa, Tommy Crickshaw; o muralismo e o artista Diego Rivera; e, para finalizar, o Federal Theatre e a peça The cradle will rock. 


\subsection{Tommy Crickshaw e o vaudeville}

Quando Hallie Flanagan, a diretora do FTP, chega à sede do projeto, ouvimos um homem em voice over, que fala nervoso sobre alunos que gostariam de atuar como ele. Diz que seriam necessários trinta anos de dedicação exclusiva para talvez conseguirem atingir o seu nível. Ele reclama por ter que ensinar as pessoas, uma vez que não é um professor e sim um artista de entretenimento. Hallie se aproxima e a atendente a informa que este senhor, Tommy Crickshaw, faz parte do Projeto de Vaudeville do FTP e está descontente com o funcionamento do projeto, ao que ele complementa que tem que ensinar sua arte a pessoas sem talento.

A partir dessa cena, podemos apontar que o referido artista, já nesse primeiro momento, se considera em uma posição diferenciada, não apenas por conta dos anos de experiência que possui, mas pelo fato de achar que essa arte é executável apenas por alguns poucos escolhidos. Crickshaw acredita estar numa posição de superioridade e não demonstra interesse em trabalhar para a ampliação do acesso às técnicas artísticas que conhece. Assim, ele se coloca de lado oposto aos intelectuais e artistas que Benjamin definiria como progressistas, por não querer compartilhar seus conhecimentos e, conseqüentemente, por não contribuir para que os espectadores se tornem também produtores. Segundo Walter Benjamin,

um escritor que não ensina outros escritores não ensina ninguém. $\mathrm{O}$ caráter modelar da produção é, portanto, decisivo: em primeiro lugar, ela deve orientar outros produtores em sua produção e, em segundo lugar, precisa 
colocar à disposição deles um aparelho mais perfeito. ${ }^{45}$

Essa postura funciona de modo duplamente negativo - por não contribuir para a reflexão e conseqüente formação dos espectadores e por conta do fato de Crickshaw ser um artista de vaudeville, arte que estava em decadência na década de 1930. Ou seja, ao não difundir sua arte, acaba por determinar seu próprio fim.

Outro aspecto importante a ser ressaltado é que Tommy Crickshaw assume uma postura aristocrática em relação ao vaudeville, que é uma forma popular de diversão das massas, marcadamente comercial e americano ${ }^{46}$. Tal postura é reforçada ao longo do filme, que apresenta diversas ocasiões em que Crickshaw refere-se a si mesmo como um grande artista e ao vaudeville como Arte. Apesar de o filme explicitar em diversos momentos a condição de trabalhador de Crickshaw, ainda assim a personagem não demonstra estar consciente disso. Ao mesmo tempo em que ele está sendo atendido na sede da WPA, é mostrada uma enorme fila de pessoas do lado de fora, que buscam trabalho para tentar sobreviver, e deduzimos que ele também teve que fazê-lo em um momento anterior, visto que desempenha uma função ligada ao projeto. Todavia, o fato de a própria realidade histórica o impelir a um certo nível de conscientização - e, ainda assim, ele a repelir - demonstra que essa consciêcia não surge automaticamente, mas a partir de uma tomada de posição do próprio artista.

Em diversos momentos o ventríloquo se manifesta como avesso à política, e afirma que trabalha em um teatro, não em um comitê político. Crickshaw diz que seu objetivo é apenas entreter as pessoas e fazê-las rir. Contudo, ele é um dos personagens que mais

\footnotetext{
${ }^{45}$ Ibidem, p. 132.

${ }^{46}$ Para saber mais sobre o surgimento e caracterização do vaudeville, cf. Lewis, Robert M. From traveling show to vaudeville: theatrical spetacle in America, 1830-1910. Baltimore: The John Hopkins University Press, 2003.
} 
fortemente marcam seu posicionamento, visto que está o tempo todo acusando os outros de "vermelhos" e de comunistas e, em grande parte de suas falas, mostra uma postura anticomunista. Algo que nos provoca um certo estranhamento em relação às suas atitudes e à postura que assume é o fato de que, em uma cena posterior, nos é sugerido que o ventríloquo teria tido ligações com o partido comunista, como podemos observar no "diálogo" entre ele e seu boneco (Melvin):

Melvin: Que herói você é! Sr. Nobre-delator-de-seus-amigos-agora-todossão-despedidos Crickshaw. Que hipócrita! Você já acreditou em algo, Tommy.

Crickshaw: Cale a boca!

Melvin: A que ponto você chegou, Tommy Crickshaw? Onde está o jovem camarada que conheci? Vamos fazer o nosso antigo ato. Mais uma vez, em nome dos velhos tempos? Vamos, Tommy.

Durante essa cena, observamos o reflexo de Tommy Crickshaw em dois espelhos, ou seja, vemos sua representação e não ele em si. Podemos interpretar essa imagem como a representação do conflito de duas perspectivas de mundo que convivem dentro da personagem: suas vivências enquanto jovem comunista e suas convicções de artista avesso à política. Essa divisão de duas concepções opostas se materializa de forma concreta ao vermos refletidas as duas imagens da mesma personagem. Porém, no momento em que Melvin pergunta “a que ponto você chegou?”, há um close no espelho da esquerda, momento no qual vemos apenas a imagem de Crickshaw enquanto ouvimos a voz do boneco. Ao terminar seu discurso, Melvin começa a cantarolar e Tommy se espanta, olhando em sua direção. A câmera se movimenta e mostra o boneco e o ventríloquo. Faz-se necessário destacar que, apesar de parecer uma discussão de idéias diferenciadas, é Crickshaw quem dá voz ao boneco e, dessa 
maneira, essas afirmações partem dele próprio, explicitando o conflito que se impõe ao ventríloquo. Podemos dizer que se caracteriza uma espécie de esquizofrenia, quando o artista transfere para o boneco aspectos de sua personalidade e histórico de vida com os quais não consegue lidar, pois são opostos às suas perspectivas. Entretanto, essa esquizofrenia não é de natureza indiviual e psicologizante, tendo sua origem em aspectos sociais e políticos. Isso porque um posicionamento político progressista entraria em conflito com sua postura em relação ao seu trabalho e com sua falta de militância.

Essa oposição se intensifica ainda mais no palco, enquanto Tommy Crickshaw representa o antigo ato, ao qual acrescenta comentários sobre sua situação naquele momento. A cena se inicia com um plano geral da platéia, que contém um número pequeno de pessoas, todas aplaudindo. Há um contraste com a cena imediatamente anterior, em que centenas de pessoas adentram o Venice Theatre, onde será representada a peça The cradle will rock. Observamos, então, Crickshaw com seu boneco no palco, pronto para iniciar sua atuação. No entanto, permanece em silêncio, mostrando em seu rosto uma expressão angustiada. Vemos sua cúmplice Hazel Huffman entrar no teatro e os seus pupilos atrás da cortina, ao lado do palco. Há um close no ventríloquo e, em seguida, no boneco, que parece olhar para Tommy Crickshaw, como se estivesse cobrando uma atitude dele. Vemos novamente um plano dos pupilos, de Hazel, de Crickshaw, do boneco. O ventríloquo suspira e começa a falar:

Crickshaw: Você sabe que os tempos estão difíceis quando olho pra você e vejo lenha.

Melvin: Hey! O que você está dizendo?

Crickshaw: Bem, meu amigo de carvalho, o Sr. Roosevelt nos despediu.

Melvin: Cortes de despesas?

Crickshaw: Política.

Melvin: Eu disse que você não deveria ter delatado meus amigos.

Crickshaw: Amigos? 
Melvin: Uh-oh.

Crickshaw: Você disse amigos? Aqueles vermelhos são seus amigos?

Melvin: Sinto muito, camarada.

Crickshaw: Camarada?

Melvin: Somos todos camaradas e não descansaremos até que todo o país seja vermelho.

Crickshaw: Conheço este boneco como a palma da minha mão, eu juro. Em minhas próprias mãos um revolucionário?

Melvin: Senhoras e senhores. Este homem explora meu trabalho para seu lucro próprio. Este capitalista não me paga nada, me faz trabalhar quando ele quer. Eu vivo em um apartamento que parece uma caixa.

Crickshaw: Você é uma marionete!

Melvin: Marionetes! É assim que ele nos chama, meus irmãos e irmãs.

Crickshaw: Não vocês, gente!

Melvin: Se somos marionetes, então eu digo: Marionetes, de pé! De pé para o chamado dos marionetes trabalhadoras em todos os lugares. Ataquem as barricadas! Tumulto nas ruas! [em seguida, começa a cantar a Internacional]

Ao contrário de seu posicionamento ao longo de todo o filme, nesse ato o ventríloquo atribui o fim do Federal Theatre a razões políticas. Além disso, dá voz ao protesto do boneco contra condições exploratórias de trabalho por capitalistas e a um chamado para a revolta por parte dos trabalhadores, convocados a se unirem para lutar por seus direitos. Porém, apesar de ser Crickshaw quem fala por intermédio do boneco, o ventríloquo demonstra resistir a seus próprios argumentos, como se não se reconhecesse em seu próprio discurso.

Essa relação entre o personagem e o boneco nos remete às teses sobre o conceito de história de Benjamin, em que este apresenta o boneco chamado "materialismo histórico": 
Como se sabe, deve ter havido um autômato, construído de tal maneira que, a cada jogada de um enxadrista, ele respondia com uma contrajogada que lhe assegurava a vitória da partida. Diante do tabuleiro, que repousava sobre uma ampla mesa, sentava-se um boneco em trajes turcos, com um narguilé à boca. Um sistema de espelhos despertava a ilusão de que essa mesa de todos os lados era transparente. Na verdade, um anão corcunda, mestre no jogo de xadrez, estava sentado dentro dela e conduzia, por fios, a mão do boneco. Pode-se imaginar na filosofia uma contrapartida dessa aparelhagem. O boneco chamado "materialismo histórico" deve ganhar sempre. Ele pode medir-se, sem mais, com qualquer adversário, desde que tome a seu serviço a teologia, que, hoje, sabidamente, é pequena e feia e que, de toda maneira, não deve se deixar ver. ${ }^{47}$

O boneco se posiciona a partir de conceitos marxistas, contrários a tudo que o Tommy Crickshaw acredita e argumenta em suas falas ao longo do filme. Entretanto, sendo ele um boneco, não consegue falar por si só, uma vez que, assim como o jogador de xadrez, é apenas um autômato, que necessita do ventríloquo para ser seu sujeito e atuar por ele. Crickshaw, por outro lado, recusa qualquer resquício de um possível passado comunista, mas também não tem possibilidade de ser ventríloquo sem o boneco, que materializa seu passado e seu histórico. Sendo assim, Crickshaw, que é de fato sujeito, nega a historia dele materializada no boneco e coloca toda a história reificada no boneco, externalizada e alienada dele. A cena surge do conflito entre o autômato, documento histórico que precisa do sujeito para que se torne ativo, e Crickshaw, sujeito que tenta negar sua história de esquerda concretizada no boneco, do qual depende para definir a si próprio como um ventríloquo . Há um choque entre o inconsciente político que o chama para a luta de classes e o esforço de Crickshaw em negar esse inconsciente, tentando constantemente suprimi-lo.

\footnotetext{
${ }^{47}$ Löwy, Michael. Walter Benjamin: aviso de incêndio: uma leitura das teses "Sobre o conceito de história". São Paulo: Boitempo, 2007, p. 41.
} 
Um artista com o histórico semelhante ao de Tommy Crickshaw não representa desse modo um aliado para a realização da revolução. Faz-se necessário que ele tome uma posição e parta para a ação efetiva, caso queira promover mudanças na sociedade. A visão dos marxistas que constituíram a II e III Internacional era de que a História como uma máquina que conduz automaticamente ao triunfo do socialismo. Sendo assim, o desenvolvimento das forças produtivas, o progresso econômico e as "leis da história" levam necessariamente à crise final do capitalismo e à vitória do proletariado. Pensando desse modo, estão observando apenas o autômato e esquecendo que é necessário haver um sujeito para manipulá-lo e, assim, ganhar a partida. Não basta apenas a consciência de um processo para uma ação transformadora. Faz-se igualmente necessário que o artista se posicione enquanto trabalhador, a fim de lutar de maneira eficaz contra as classes dominantes. Para Löwy, ganhar a partida tem duplo sentido:

1) interpretar corretamente a história, lutar contra a visão da história dos opressores;

2) vencer o próprio inimigo histórico, as classes dominantes - em 1940: o fascismo. ${ }^{48}$

Ainda segundo Löwy:

Para Benjamin, os dois sentidos estão intimamente ligados na unidade indissolúvel entre a teoria e prática: sem uma interpretação correta da história, é difícil, se não impossível, lutar de maneira eficaz contra o fascismo. A derrota no movimento operário marxista diante do fascismo - na

\footnotetext{
${ }^{48}$ Ibidem, p. 41-42.
} 
Alemanha, na Áustria, na Espanha, na França - demonstra a incapacidade desse boneco sem alma, desse autômato vazio de sentido, de "ganhar a partida" - uma partida em que se decide o futuro da humanidade. ${ }^{49}$

Podemos dizer que tanto o ventríloquo, como a arte da qual é representante, o vaudeville, têm potencial revolucionário que não é utilizado. O vaudeville apresenta uma natureza episódica, com estruturação autônoma das cenas, que não possuem texto e são baseadas na ação física. Tendo em vista que estamos analisando esses aspectos inseridos na perspectiva do filme $O$ poder vai dançar, não é ilícito imaginar uma possível familiaridade entre tais aspectos e o universo da forma épica. No entanto, esse potencial não é aproveitado de maneira produtiva, uma vez que desde o princípio tal forma artística é utilizada de modo reificado, como uma mercadoria lucrativa. Representa desse modo um grande avanço nas forças produtivas, porém acompanhado de um retrocesso ideológico.

Diante desses aspectos observados, emerge a pergunta: qual seria essa possibilidade de um caminho progressista para o vaudeville?

Podemos citar os exemplos de alguns artistas tais como Buster Keaton e Charles Chaplin, que aproveitaram sua experiência e conhecimento e passaram a atuar no cinema. Essa nova forma artística, que surgiu no final do século XIX, permitia avanços ainda maiores, por se caracterizar pela perfectibilidade e muito maior acessibilidade, em nível mundial.

Desse modo, Tommy Crickshaw opta por não utilizar esse potencial da arte que realiza e, ao mesmo tempo, nega quaisquer ideais ou postura crítica que poderiam ter relação com seu passado comunista, por acreditar que um artista não deveria se envolver em questões políticas. Sendo assim, sua preocupação é apenas de entreter seu público, realizar sua arte, sem

\footnotetext{
${ }^{49}$ Ibidem, p. 42.
} 
qualquer interesse em difundir as técnicas artísticas que conhece, não acreditando que existisse possibilidade de fim do vaudeville, mesmo isso já sendo uma realidade naquele momento. É interessante destacar que há um diálogo produtivo entre as cenas do ventríloquo e as de ensaios da peça Fausto, que se repete em diversos momentos. A venda da alma em troca de longevidade e sabedoria entra em contradição na figura de Crickshaw, que vende a alma acreditando que atingirá a mesma longevidade, além do reconhecimento de um grande artista, mas ao fazê-lo contribui com o fim de sua arte.

Ao longo de seu ato final ouvimos pessoas gritando da platéia, outras o mandando sair do palco, e várias se retirando do teatro. Observamos, portanto, a representação da morte dessa forma artística, que não encontra mais eco no publico e deixa de desempenhar qualquer papel de entretenimento ou social. Os aplausos que recebeu antes de atuar se opõem ao silêncio que permanece no final. Nesse momento, mais uma vez age de forma contrária à imagem que construiu ao longo da narrativa, quando repudia seu boneco, que ele afirmara nunca abandonar. $\mathrm{Na}$ realidade não apenas deixa o boneco no palco, mas sua crença na permanência de sua arte e de sua figura de artista e a certeza de que as transformações sociais aconteceriam naturalmente, de modo automático. Acena, se despedindo de tudo que o boneco representa. Na seqüência final do filme, assistimos ao cortejo fúnebre do boneco, nomeado de Federal Theatre, mas que possui uma dimensão ainda maior se levarmos em conta os aspectos apontados. Representa, assim, a morte dessa visão de mundo e dessa confiança ingênua no autômato. Traz à tona a necessidade de ação por parte do proletariado, para a transformação da realidade que vivem. 


\subsection{Diego Rivera e seu mural no Rockefeller Center}

Por volta de aproximadamente trinta minutos após o início do filme, ouvimos um trecho da música Gotta go to work again ${ }^{50}$, na qual uma pessoa afirma ter comprado uma casa, uma limusine e um iate, mas enquanto bebe seu champanhe é acordada pelo despertador e se dá conta de que estava sonhando e que é hora de ir trabalhar. Observamos Nelson Rockefeller ${ }^{51}$ saindo de seu carro e entrando em uma casa em más condições de conservação. Quando já está no interior do local, chama por Diego Rivera. Em seguida, a câmera mostra um plano geral do que parece ser o estúdio do pintor mexicano, que está ao fundo pintando um quadro, ao mesmo tempo em que Frida Kahlo - sua esposa - lê um livo e não tem qualquer reação ao ver Rockefeller entrando no lugar. Mesmo depois, quando Rivera apresenta o visitante a ela, Frida não faz qualquer menção de cumpimentá-lo.

Rockefeller faz uso de algo que têm em comum com o pintor - a amizade com Margherita Sarfatti - para iniciar a conversa. A reação do artista mexicano é a mesma que Sarfatti tivera ao ouvir seu nome, fazendo referência a uma época agitada em Paris. Nelson Rockefeller diz que encontrou com a italiana na mesma data e a elogia bastante, dizendo que é culta e ótima apreciadora de arte. Rivera corta o assunto e diz "então...", esperando que o capitalista diga o real motivo de sua visita, até o momento não explicitado. A relação que os dois estabelecem é formal, tratando um ao outro por "Mr. Rivera" e "Señor Rockefeller", respectivamente. Na composição visual da cena, ambos se encontram no mesmo plano, estando em condições iguais. De forma amigável, Rockefeller faz uma proposta de trabalho

\footnotetext{
${ }^{50}$ Com letra de Milton Pascal e música composta por Edgar Fairchild, esta canção de 1936 foi também usada na trilha sonora do filme My man Godfrey (1936).

${ }^{51}$ Personagem real baseado em uma personalidade do período, membro de uma das famílias mais ricas do mundo, considerada símbolo da prosperidade norte-americana.
} 
para Diego Rivera: pintar um mural no lobby do Rockefeller Center, prédio em construção naquele momento.

É interessante notar que Rockefeller ao fazer isto olha para as modelos que se encontram no recinto e não para Rivera. Podemos dizer que as modelos são reificadas, consumidas como objetos pelo olhar de Nelson Rockefeller, assim como o é a forma que se relaciona com o artista, como algo que quer comprar. Conforme fica ilustrado em outros momentos do filme, é justamente essa a relação que ele estabelece com a arte, como por exemplo quando diz se sentir extraordinário por estar perto de um Da Vinci ou Michelangelo. Diego Rivera igualmente não olha para Rockefeller, mas sim para o seu quadro e permanece trabalhando, sendo essa portanto sua única preocupação, a de realizar o seu trabalho artístico. Em seguida, olha rapidamente para Nelson Rockefeller e questiona o valor que será pago. Ele responde: "vinte e um mil dólares, com tudo incluso, materiais e assistentes".

Diego Rivera fez parte do movimento muralista mexicano, ocorrido logo após a Revolução Mexicana de 1910, que tinha como traço fundamental a intervenção social e política através da arte. Os arttistas queriam que ela fosse pública e coletiva, produzindo suas obras em lugares acessíveis, para que todos as pudessem ver, e como forma de impedir que essas obras acabassem em propriedade de algum abastado colecionador. Os murais caracterizavam-se pela ausência de qualquer imposição concernente ao estilo e à temática e pela liberdade dos artistas na escolha dos seus temas.

Rivera vem portanto de um histórico de ação revolucionária através da arte, e o contexto em que se estabeleceu como artista nos demonstra uma grande liberdade de forma e conteúdo nas suas obras. Seus afrescos inclusive marcam, segundo Löwy, uma verdadeira guinada na história da cultura latino-americana, devido à sua desmistificação do Conquistador e simpatia pelos guerreiros indígenas. Além da forte atuação por meio de suas obras, também 
fundou, juntamente com André Breton e Leon Trotski, a FIARI (Federação Internacional da Arte Revolucionária e Independente), de vida efêmera, mas importância histórica crucial. Dentre os propósitos estabelecidos por eles, estavam:

nenhuma barreira, nenhum tipo de controle, nenhum limite aos sonhos, à cultura ou à arte; um libelo pela mais plena e absoluta liberdade de expressão, sem qualquer tipo de amarras; o mais vigoroso repúdio a toda e qualquer forma de autoritarismo ou dirigismo; [a exigência de que] os meios materiais devem ser postos sem limite ou controle de qualquer espécie, a serviço do ser humano e da arte; [a proposição que] a arte jamais deve ser reduzida a serviçal do capital; e o repúdio à barbárie das guerras e do autoritarismo. $^{52}$

Com o objetivo de fugir da repressão política e por conta da maior demanda por seus trabalhos, Diego Rivera opta for ficar um período nos Estados Unidos, a partir do final da década de 1920. A princípio, ele tem sua entrada no país impedida, por conta de sua ideologia comunista. Mas, após a intervenção de um influente apreciador de sua arte, consegue o visto.

Rivera era sempre questionado sobre a contradição entre seus ideais e prática, uma vez que aceitava pagamento de pessoas com fortunas particulares, o que resultava em críticas tanto de esquerdistas como de direitistas. Sua resposta aos opositores de esquerda era de que eles deveriam tornar a revolução real, de modo que os muros seriam coletivos, ou então ele não teria escolha a não ser pintar os muros que conseguisse com as remunerações oferecidas. Em $O$ poder vai dançar, tais aspectos são também colocados em questão, quando temos representada a contratação do pintor mexicano pelo capitalista Nelson Rockefeller.

\footnotetext{
${ }^{52}$ Trotski, Leon, Breton, Andre; Rivera, Diego. Manifesto por uma arte revolucionária
} 
$\mathrm{Na}$ continuação da cena descrita, Rockefeller contraria o conselho dado por Margherita Sarfatti para que se mantivesse sóbrio, e aceita o drink oferecido por Diego Rivera. Há um corte para apresentação de trechos de outras narrativas, nas quais podemos observar a apresentação e aprovação de Revolt of the beavers ${ }^{53}$ por Hallie Flanagan; a já descrita contratação da futura atriz Olive Santon para o Projeto 891; a participação de Tommy Crickshaw no encontro daqueles que são contrários ao Federal Theatre Project; e uma conversa entre Flanagan e Harry Hopkins sobre a criação do comitê para investigar Comunismo na WPA - o Comitê de Atividades Anti-Americanas -, com o qual Hopkins garante que ela não deve se preocupar, já que são apenas "um bando de políticos com a intenção de estar nas manchetes dos jornais". No momento subseqüente, vemos mais um trecho do encontro onde está Crickshaw. Ele expressa sua opinião a respeito do Federal Theatre Project:

pessoalmente, eu não acredito que haja qualquer espaço para avanço se você não concorda com eles ou se você não se iguala a eles na política, se você não tem a mesma visão política que eles. E além disso... Vermelhos não são divertidos. Eu não acho que eles sejam divertidos.

Para refutar o argumento de Crickshaw, voltamos ao estúdio de Rivera, no qual vemos Rockefeller, as modelos, Diego Rivera e sua esposa Frida dançando e se divertindo bastante ao som de What a Little Moonlight can do, na voz de Billie Holiday. O título, que também é o verso inicial da música pode se referir tanto à luz do luar, como a fazer um trabalho extra, especialmente um que envolva alguma desonestidade. A luz da lua é portanto uma metáfora

\footnotetext{
${ }^{53}$ Peça produzida pelo Federal Theatre que narrava a história de um grupo de castores que, cansados dos desmandos do poderoso The Chief, o expulsam da Beaver Land e instalam um sistema igualitário em sua comunidade.
} 
da moeda que brilha e pode determinar escolhas. A música funciona ao longo de toda a cena como uma espécie de narrador, em alguns momentos indicando o que vai ocorrer e em outros comentando as ações que estão ocorrendo.

Na próxima cena dessa narrativa, podemos analisar mais uma vez a composição dos planos em relação ao posicionamento das personagens Rivera e Rockefeller. Vemos o pintor sobre os andaimes, situado acima de seu patrono, estando o mural em proporções maiores que ambos. Eles conversam sobre a obra e Rivera explica alguns dos temas que trata, que demonstram os avanços da ciência e tecnologia, aspectos de crítica social e de oposição aos que detém o poder. Em certo momento da conversa, Nelson Rockefeller pergunta:

Rockefeller: E estas pessoas bem vestidas, quem são?

Rivera: O que você vê?

Rockefeller: A alta sociedade, em uma espécie de festa.

Rivera: Isso mesmo! Os ricos decadentes. Acima de suas cabeças está uma célula contaminada com sífilis.

Rockefeller: Sífilis? Os ricos em geral?

Rivera: Não, em específico.

Rockefeller: Você não está falando de mim, está?

Rivera: Mas você não tem sífilis, né?

Rockefeller: Claro que não. Não tenho... E lá em cima? É algum tipo de guerra?

Rivera: É um campo de batalha. Homens no holocausto da guerra. E abaixo deles, há trabalhadores desempregados apanhando da polícia. Você gostou?

A resposta de Rockefeller é mostrada em sua expressão facial, que demonstra seu choque com todos os elementos ilustrados no mural, que atacam de forma direta o que ele e seus semelhantes representam. Em oposição, Rivera ri com satisfação, uma vez que durante todo o 
diálogo manteve-se no comando da situação, fato mais uma vez reforçado na composição do enquadramento da cena. Podemos inferir que nessa seqüência a obra dá poder ao artista, que está em posição de superioridade em relação ao "patrão". Reforçando tal afirmação, há ainda a utilização de ponte sonora: enquanto observamos a imagem de Nelson Rockefeller, ouvimos Aldo Silvano - que representa o lider sindicalista na peça The cradle will rock - cantar "você não consegue parar o temporal, nem com todo seu dinheiro...”. Há um corte para o ensaio no teatro e o ator continua "porque quando o vento soprar, quando o vento soprar, o poder vai dançar”. Desse modo, torna-se ainda mais vigorosa a crença no poder da arte e dos artistas.

São encontrados outros elementos no mural que não são mencionados no diálogo reproduzido acima. Para apontar alguns deles, utilizaremos como base a análise da obra pelo pesquisador Rafael Quinsani, que afirma que:

com um olhar amplo, podemos configurá-la como uma proposta de narrativa de um processo histórico humano. A obra possui um centro que atrai o primeiro olhar. Neste centro está a figura de um homem, caracterizado como um operário, que comanda uma máquina com várias engrenagens. Não há uma atração de mais evidência quando dirigimos o olhar para as extremidades. $\mathrm{O}$ olhar tanto pode se dar da esquerda e para cima, como da esquerda para baixo, o mesmo valendo para o lado direito. Este movimento para abarcar o olhar de toda a obra coloca explicitamente as comparações que o autor deseja que o espectador realize. ${ }^{54}$

Outro elemento interessante destacado por Quinsani é o fato de que o exército encontrado à esquerda do mural não apresenta rostos individuais. Todos estão cobertos por

\footnotetext{
${ }^{54}$ Quinsani, Rafael Hansen. A revolução na encruzilhada: uma análise da arte revolucionária do muralismo mexicano a partir da imagem $O$ homem controlador do universo, de Diego Rivera.
} 
máscaras, em oposição ao povo, cujas feições são retratadas de forma clara. O crítico ainda complementa "se o exército impõe a força pelas armas e dá-se destaque às baionetas, o povo impõe a força pelas idéias representadas pelas bandeiras". Assim como diversas obras de Rivera, este mural tem um caráter narrativo e histórico bem marcados, em que o verdadeiro herói é a massa.

Contam relatos que, após determinado tempo de trabalho no mural, era possível notar uma figura conhecida, descrita por Rivera em seus esboços apenas como um líder dos trabalhadores, mas que naquele momento poderia ser reconhecido como uma representação de Vladimir Lênin. Segundo o professor Robert $\operatorname{Scott}^{55}$, a exaltação dos ânimos começou com a publicação de uma matéria no jornal New York World Telegram com o título "Rivera pinta cenas de atividade comunista e John D. [Rokefeller] Jr. paga a conta”. Desse modo, Nelson Rockefeller e outras pessoas tentam convencer o artista a remover o retrato de Lênin e substituí-lo por outra personalidade ou por um rosto desconhecido. Diego Rivera responde às cartas dizendo

(...) eu entendo completamente o seu ponto de vista, no tocante aos negócios que acontecem em um edifício comercial, embora eu esteja certo de que tal tipo de pessoa que se ofenderia com um retrato de um grande homem já falecido, teria o mesmo sentimento, devido à sua mentalidade, em relação ao próprio conceito de minha pintura como um todo. Por essa razão, ao invés de mutilar a obra, eu prefiro a destruição material dela inteira, mas preservando pelo menos a integridade de tal obra. Ao falar da integridade da obra, não me

\footnotetext{
${ }^{55}$ Scott, Robert L. Diego Rivera at Rockefeller Center: Fresco Painting and Rhetoric. Western Journal of Speech Communication, n. 41, Spring 1977, p. 70-82. Disponível em: http://web.utk.edu/ glenn/Scott-Rivera.pdf
} 
refiro apenas à estrutura lógica da pintura, mas também à sua estrutura plástica. ${ }^{56}$

Chega a propor contrabalancear a figura de Lênin com a de um americano, como Abraham Lincoln, sem sucesso.

No filme não há menção à manchete do jornal, mas é representada a tentativa de negociação entre Rivera e Rockefeller, por conta do fato de que o capitalista não aceita a ilustração de Lênin no saguão de seu prédio. Na composição visual da cena, o artista se encontra em plano superior, em cima do andaime, e ambos de forma amigável tentam negociar. Depois de Diego Rivera se mostrar intransigente quanto a retirar o revolucionário russo ou substituí-lo por uma outra figura, há uma mudança de atitude e feição de Nelson Rockefeller, que usa palavrões e aumenta seu tom de voz, assumindo uma atitude agressiva, mas ainda em um plano inferior no enquadramento da cena. Ele diz "isso não é uma revolução, isso é os Estados Unidos e não a Rússia!”

Se pensarmos na figura histórica do artista Diego Rivera, podemos sugerir que sua ação foi consciente, por conta de sua vivência e histórico anterior, e portanto que sua intenção era a de um combate revolucionário, através da pintura de um mural no lobby do prédio do Rockefeller Center, propriedade de um capitalista, denunciando as conseqüências do sistema em que pessoas como Rockefeller estariam a frente. Sendo assim, a destruição do mural seria indiferente, contanto que fosse dado o recado. Na verdade, conforme observa Horace Gregory,

\footnotetext{
${ }^{56}$ Carta de Diego Rivera a Nelson Rockefeller em 06 de maio de 1933. (tradução nossa). Fonte: http://xroads.virginia.edu/ MA04/hess/RockRivera/correspondence.html (será disponibilizada nos anexos toda a correspondência entre eles a respeito dessa controvérsia)
} 
os martelos criaram um símbolo, ao invés de destruí-lo (...). O espaço vazio é agora um testemunho melhor da causa da arte e revolução do que a obra em si seria. ${ }^{57}$

Para complementar, Rivera ainda tratou de pintar uma réplica do mural em tamanho reduzido no Palacio de Bellas Artes, situado no México, com o título El hombre controlador del universo, no qual incluiu mais um personagem entre os ricos decadentes, bem próximo dos vermes observados no microscópio: John D. Rockefeller Jr., além de mais elementos comunistas.

No entanto, a personagem de Rivera construída no filme e a seqüência das cenas nos levam a crer que ele, apesar de ser um artista revolucionário, não reconhece sua condição de trabalhador e se considera, desse modo, livre das determinações às quais se submetem os trabalhadores em geral, acreditando ter liberdade na expressão de suas opiniões, conhecimentos e habilidades técnicas. Construindo a personagem dessa forma, Tim Robbins põe também em questão o papel do artista e do intelectual como produtores. Conforme Benjamin argumenta no texto "Autor como produtor",

\footnotetext{
por mais revolucionária que pareça, a tendência política está condenada a ser contra-revolucionária enquanto o artista permanecer solidário com $\mathrm{o}$ proletariado somente ao nível de suas convicções. ${ }^{58}$
}

Faz-se necessário ao artista reconhecer que ele é também um proletário, ou seja, que “o lugar do intelectual na luta de classes só pode ser determinado, ou escolhido, em função de sua

\footnotetext{
${ }^{57}$ Gregory, Horace apud Scott, Robert. Diego Rivera at Rockefeller Center: Fresco Painting and Rhetoric.

${ }^{58}$ Benjamin, Walter. Op.cit., p.125-126.
} 
posição no processo produtivo." 59

As conseqüências da atitude de Rivera são apresentadas em uma cena posterior, em que ele é impedido de voltar ao trabalho por alguns funcionários de Rockefeller, juntamente com outras pessoas que nos parecem policiais. Nesse quadro, a composição visual dos planos se inverte e Diego Rivera encontra-se em posição inferior no enquadramento da cena, com as forças de opressão entre ele e sua obra. Ele corre e luta contra essa realidade, mas é perseguido. Então grita para sua esposa, que nesse momento está subindo as escadas, para avisar os companheiros que a "guerra começou". Apesar de continuar lutando contra os fatos, Diego pega na mão o cheque oferecido pelo funcionário de Rockefeller, com pagamento integral pelos serviços prestados, e continua indagando o que será feito de seu mural, agora apontando para aqueles que questiona com a mesma mão que segura o cheque. Mantém seus ideais, mas não tem como se desligar do mundo do trabalho, do qual depende para sobreviver.

Margherita Sarfatti, ao falar com Rivera sobre este assunto, resume aquilo que, em sua opinião, ele se recusou a enxergar: ao ser contratado para fazer um serviço e receber por isso, estava se submetendo às regras e ideais daquele que o contratou. Ela diz

você foi contratado para realizar um trabalho. Agora seu patrão não gostou do que fez. Pinte sua revolução às suas custas. Vá pintar um mural de graça na Liga dos Jovens Comunistas.

Ele ainda se mostra apegado aos seus ideais e acredita que, mesmo recebendo dinheiro para realizar sua obra artística, tem liberdade de criação. Nos termos da personagem de Marc Blitzstein, em outro momento do filme, ele vende sua arte, mas não sua alma. 
Conforme Diego Rivera afirmou anteriormente, não há nada inapropriado na arte. Entretanto, sua postura, apesar de idealista, não se desconecta da função política da arte. Nas palavras de Rivera, Trotski e Breton,

ao defender a liberdade de criação, não pretendemos absolutamente justificar o indiferentismo político e longe está de pensamento querer ressuscitar uma arte dita "pura" que de ordinário serve aos objetivos mais do que impuros da reação. Não, nós temos um conceito muito elevado da função da arte para negar sua influência sobre o destino da sociedade. Consideramos que a tarefa suprema da arte em nossa época é participar consciente e ativamente da preparação da revolução. No entanto, o artista só pode servir à luta emancipadora quando está compenetrado subjetivamente de seu conteúdo social e individual, quando faz passar por seus nervos o sentido e o drama dessa luta e quando procura livremente dar uma encarnação artística a seu mundo interior. ${ }^{60}$

Nesse aspecto Diego Rivera se opõe à personagem de Tommy Crickshaw, à medida que o ventríloquo se acomoda no pensamento que “quer ressuscitar uma arte dita 'pura' que de ordinário serve aos objetivos mais do que impuros da reação" ${ }^{\text {"61 }}$. Sendo assim, ao optar por uma arte "desconectada da realidade", ele na verdade está dando munição a quem ele deveria enfrentar. O pintor mexicano, por outro lado, não apenas tem os conceitos políticos que o colocam ao lado do proletariado, mas também disponibiliza uma transformação das formas e forças produtivas, de modo a modificar o aparelho de produção. Segundo Benjamin, isso

o transforma de fornecedor do aparelho de produção intelectual em

\footnotetext{
${ }^{60}$ Trotski, Leon, Breton, Andre; Rivera, Diego. Op.cit.

${ }^{61}$ Ibidem.
} 
engenheiro que vê sua tarefa na adaptação desse aparelho aos fins da revolução proletária.

Desse modo, apesar de não acreditar que esteja sujeito às mesmas regras que os proletários, ainda assim assume uma posição progressista e revolucionária, que podemos definir como uma espécie de "estratégia de guerrilha", já que atua de forma revolucionária utilizando-se do aparato burguês.

Podemos estabelecer um paralelo entre a personagem de Diego Rivera e o cineasta Tim Robbins que, para expressar sua arte - que, assim como o mural, é de produção e recepção coletiva - encontra limites ainda maiores do que os enfrentados por Rivera, já que o financiamento de sua obra e as relações de produção em que se encontra estão no terreno da indústria cultural. Ele também está inserido na luta entre opressores e oprimidos e deve saber utilizar-se desses meios e, ao mesmo tempo, transmitir o seu recado, propor as questões que lhe interessa discutir, e lidar com a possibilidade de ter o seu "mural" destruído. Todavia, ficar "em cima do muro" não é uma opção para Tim Robbins, já que isto significaria confirmar a visão dos vencedores. 


\subsection{The Cradle Will Rock e o Federal Theatre Project}

As personagens Marc Blitzstein, Orson Welles e John Houseman estão no Twenty-one Club, após a aprovação de The Cradle Will Rock pela diretora do Federal Theatre, Hallie Flanagan:

\footnotetext{
62 Similares aos patronos da Renascença, esses "príncipes" modernos davam dinheiro para exposições em museus e apoio às danças, teatro, musica e companhias de ópera, entre outros, por conta do status social proporcionado pelo patrocínio às artes. Para mais informações, Cf.: Martorella, Rosanne. Art and business: an international perspective on sponsorship. Westport: Greenwood Publishing Group, 1996.

${ }^{63}$ Nome de uma rede de hotéis extremamente luxuosos.

${ }^{64}$ Antiga mansão de um diretor de fábrica transformada em clube dos trabalhadores na União Soviética.
} 
Blitzstein: Eu não tenho problema com dinheiro. Eu preciso dele do mesmo modo que todo mundo.

Welles: Sei.

Blitzstein: O problema é o que você faz pelo dinheiro. Onde você traça o limite?

Houseman: Boa pergunta!

Blitzstein: É disso que trata minha peça. The Cradle Will Rock é sobre prostituição. Prostituição da educação, da imprensa, dos tribunais, e o mais importante...

Welles (dirigindo-se ao garçom): Rothschild ${ }^{65}$ de 1929.

Blitzstein: Mais importante para você e para mim, Orson, prostituição do artista. Onde você traça o limite? Você traça um limite? Quanto tempo falta para você começar a fazer comerciais de sabonetes?

Ao longo desse diálogo, Marc Blitzstein questiona Orson Welles qual seria o limite entre ter seus trabalhos artísticos financiados e prostituir-se, questão essa que se coloca ao longo de toda a peça que, conforme já explicitado anteriormente, tem uma prostituta como personagem principal, que o faz para sobreviver e tentar fugir da fome. Segundo as palavras de Brecht no filme, não é suficiente mencionar somente esse tipo de prostituição, denunciando apenas os problemas sociais que levam a ela. Faz-se necessário apontar os outros tipos de prostituição: nas mansões, igrejas, universidades e nos sindicatos. É exatamente isso que faz o compositor, permitindo que conheçamos, por meio de flashbacks, todas as maneiras como as diversas personagens se venderam para Mr. Mister.

No momento em que o autor da peça está compondo-a, aponta como verdadeiras prostitutas os policiais, o médico especialista, o editor do jornal, o presidente da universidade

\footnotetext{
${ }^{65}$ Marca tradicional de vinhos, existente desde 1853. Cf.: http://www.rothschild.info/wine/default.asp?doc=articles/cwine1-1
} 
e o reverendo, além de artistas, destacados como os maiores representantes desse grupo. Em um trecho da peça, que apesar de não estar no filme está intimamente relacionado com o tema tratado no mesmo, podemos observar tal ponto de vista explicitado:

Yasha e Dauber: Convide-me de novo e de novo, Mrs. Mister, nos convide novamente, nós adoramos isso... Por favor, de vez em quando, nos convide novamente. Em qualquer momento que for conveniente, e nós iremos; quando não for, nós seremos tolerantes. A não ser que você tenha encontrado algum outro parasita. Porque nós amamos sentar no colo de sua suntuosa e superabundante ostentação. Apesar de ser apenas de sexta à noite até domingo. Seus convidados são repulsivos, sua comida é pesada demais. Nós comemos e bebemos e arrotamos. E estamos saciados e indispostos e entediados.

(...)

Yasha: Estamos famintos. Convide-nos para jantar.

Dauber: Sim, nos convide.

Mrs. Mister: Pobres garotos! Artistas têm que comer, isso é tudo. Nós somos bons. Nós, as pessoas cheias da grana. Apenas nos use, apenas pise em nós, se é para o bem da causa.. Ah, falando em causa, eu gostaria que vocês dois se juntassem ao Liberty Committee, do meu marido. Vocês vão, né?

Yasha e Dauber: Pode inscrever a gente!

Mrs. Mister: Mas vocês não querem saber de que se trata?

Yasha e Dauber: Política? Nós somos artistas!

Os três juntos: $\quad$ E amamos a Arte pela Arte,

É esperto, pela Arte,

Intervir, pela Arte,

Com o coração, pela Arte,

E sua mente, pela Arte,

Seja cego, pela Arte

E surdo, pela Arte, 
E mudo, pela Arte,

Eles matam, pela Arte,

Toda a Arte pela Arte.

Nessa cena da peça, a esposa de Mr. Mister chega em um carro luxuoso com a buzina que toca uma música de Beethoven e os artistas Dauber e Yasha imploram para ser convidados para a casa em que a família Mister passa seus finais de semana. Ainda que as pessoas presentes sejam "repulsivas" e a comida "pesada demais", eles adoram ter a chance de viver no luxo de sexta a domingo. Para isso, em primeiro lugar se omitem de qualquer envolvimento ou preocupação com a política, assim como apontamos em relação ao ventríloquo Tommy Crickshaw e, ao fazê-lo, também já estão assumindo um posicionamento, que é contrário aos seus interesses. Aceitam participar do Liberty Committee de Mr. Mister, cujo slogan era "América, berço da liberdade / Steeltown, berço do Liberty Committee (Comitê da Liberdade)", e que foi fundado com o objetivo de combater o socialismo, comunismo, radicalismo e especialmente o sindicalismo, além de defender os interesses da família Mister e de seus iguais, grupo no qual não se incluem Yasha e Daber. Além disso, optam por negar tudo que acreditam em relação à arte, alegando que o fazem pela Arte, quando na verdade tem interesse nos privilégios que sua aproximação de Mrs. Mister pode trazer. De acordo com Susan Quinn, a situação de Blitzstein não estava muito distante daquela retratada por ele para os estéreis artistas de quem ele zomba na peça, inclusive tendo escrito a citada cena na casa de seus costumeiros anfitriões. No entanto, segundo a autora, Blitzstein se aliou ao que o crítico Alfred Kazin chamou de obstinação do momento histórico, a nova onda militante, a fúria que estava sempre no ar. E nem ele, nem seus anfitriões poderiam ser poupados. 
Conforme explicitado no primeiro capítulo desta dissertação, Marc Blitzstein utiliza-se do material histórico do período que vivencia para construir as narrativas e personagens da peça, elemento esse que se torna estrutural em sua forma, assim como na do próprio filme $O$ poder vai dançar, o que é observado inclusive cenicamente. Podemos relembrar o exemplo da cena do parque, em que o compositor se encontra em meio a uma manifestação de trabalhadores, que mencionam o fato de seus companheiros terem sofrido repressão da polícia em um protesto realizado no dia anterior. No momento seguinte, no qual não fica claro se estamos imersos na imaginação de Marc ou se estamos observando a seqüência dos fatos que observava, chega um grupo de policiais que encerra a reunião no parque com bastante brutalidade. Marc Blitzstein faz ataques verbais aos "agentes da lei" e é atingido com um golpe na cabeça. A seguir, em mais uma cena que parece ser fruto de sua imaginação, ele está na prisão, em meio às personagens da peça, que começam a atuar, utilizando-se das falas e músicas escritas por ele.

Nas palavras do produtor John Houseman, "a totalidade de The Cradle Will Rock excedia a soma de suas partes, e seu estilo estava em algum lugar entre realismo, vaudeville e oratória." ${ }^{66}$ Tais elementos são combinados com estratégias aprendidas por Blitzstein em seu contato com o teatro épico, principalmente no que tange à utilização da música e à natureza episódica da apresentação dos fatos, por meio da narração, além do incentivo para que o espectador tome decisões e assuma posições. Para Quinn, “Cradle era e ainda permanece impossível de categorizar. É parte ópera, parte comédia musical, em certos momentos fervendo com um ardor revolucionário, em alguns outros sendo cômica e em outros, sentimental”.

\footnotetext{
${ }^{66}$ Houseman, John apud Robbins \& Burns. Op. cit., p.58.
} 
Segundo Hallie Flanagan, a diretora do Federal Theatre, "não era uma peça adaptada para ser um musical, nem música ilustrada por atores, mas música + peça que se tornou algo novo e melhor que ambos". 67

No filme, Hallie utiliza diferentes termos para definir sua opinião sobre The Cradle Will Rock: "Marc, você escreveu algo revolucionário. Que eu saiba, nenhum musical lidou com conteúdos e assuntos sociais, ao mesmo tempo em que lida com temas de dramaturgia antes disso. Você está reinventando o teatro musical.”

A personagem Olive Stanton, por outro lado, tem uma experiência diferenciada em relação à peça. Ao assistir à demonstração feita por Marc Blitzstein, fica deslumbrada e atenta a todos os fatos que ele descreve. Tão logo termina a apresentação, ela se dirige ao produtor, John Houseman, para pedir autorização para fazer um teste e trabalhar como atriz na peça, o que reforça sua identificação com a peça, que trata exatamente de sua realidade, de suas vivências. Em uma cena posterior, testemunhamos o momento em que Olive canta a música de Moll. Welles comenta:

Esse é o aspecto de uma prostituta. Inexperiente, inocente, vulnerável. Eu não quero uma prostituta sem-vergonha e atraente, Jack. Eu quero uma garota que é levada a vender seu corpo por estar faminta. A quebra da bolsa em 1929 transformou muitas jovens garotas em prostitutas hesitantes.

Ela tem tudo a perder, mas ao mesmo tempo já experimentou as conseqüências da Depressão na pele e entende a importância de sua ação, cujo papel é mais do que simplesmente artístico,

\footnotetext{
${ }^{67}$ Flanagan, Hallie. Arena. New York: Limelight, 1985, p.201.
} 
é também político. Sendo assim, é justamente ela quem levanta primeiro, incentivando os demais atores a fazerem o mesmo.

Outro aspecto interessante a ser ressaltado é que na seqüência final do filme, assistimos Olive cantar a já citada música Nickel under the foot, que deu origem à peça. Mas as imagens não são todas da apresentação no teatro. A música funciona como ponte sonora, através da qual se relacionam

A platéia que assistia à peça era também composta de Olives, que provavam no seu cotidiano o sabor amargo das dificuldades que vieram com a crise. Era exatamente esse público que interessava a Marc Blitzstein:

O público do novo teatro - aquele público que, por conta de falta de informações ou de dinheiro não tinha ido ao teatro ou à ópera até recentemente, esse grupo que está ciente do que está acontecendo em termos de conflitos sociais e econômicos, e está ávido para ver apresentações teatrais que lidem com esses elementos. Esse novo público está nos portões do teatro, clamando por algo vital. ${ }^{68}$

O Federal Theater Project, conforme já apontamos, era uma divisão da Works Progress Administration e tinha a proposta de empregar artistas, escritores e diretores fora do mercado de trabalho. Sendo assim, noventa por cento da verba era destinada para os salários dos artistas empregados no projeto. Todavia, as realizações do projeto foram muito além disso, possibilitando entreter famílias economicamente impedidas de ter acesso à arte, ao mesmo tempo em que se criava arte relevante, financiando teatro e outras performances artísticas. Segundo Iná Camargo Costa, o FTP “criou uma estrutura, ainda que precária, de

\footnotetext{
${ }^{68}$ Blitzstein, Marc apud Denning, Michael. Op.cit, p. 286.
} 
âmbito nacional, e durante dois anos e meio praticamente monopolizou as atenções do teatro no país", participando do mainstream do seu tempo. O projeto generalizou para o país a experiência teatral dos grupos de agit prop e de produtores de musicais da Broadway, ao contarem com elencos grandiosos e poucos recursos cênicos. Além desse aspecto formal, é interessante destacar que o acesso ao teatro foi democratizado por intermédio do projeto, que permitiu a um número grande de pessoas, muitas delas que nunca tinham entrado em um teatro antes, assistir às peças montadas pelos grupos ligados ao projeto.

Em relação aos temas abordados pelas peças financiadas, Hallie Flanagan afirmou:

Nenhum de nós acreditava que o Federal Theatre deveria se preocupar com política, com candidatos políticos ou nomeações políticas. Ainda que fosse coerente para um teatro cuja origem estava na necessidade econômica demonstrar preocupação com as condições econômicas em algumas de suas peças, o Federal Theatre não deveria se restringir às peças com temas de cunho social, não deveria enfatizar tais temais além da medida, e deveria manter o pensamento firme que aquelas peças deveriam ser escolhidas por conta de sua qualidade teatral. Mesmo que seja verdade notável as peças que chamavam a atenção de nossos dramaturgos e de nosso público aquelas com conteúdos econômicos e sociais.

Sendo assim, o interesse crescente da população por esse tipo de peças demonstrava a tentativa de entendimento das forças sociais e econômicas que atuavam em suas vidas. The Cradle Will Rock era uma dessas peças, e seu conteúdo estava intimamente relacionado com os eventos históricos do período em que foi composta. Segundo Denning, 
Blitzstein escreveu a ópera em cinco semanas, no verão de 1936, logo após John L. Lewis anunciar a formação do Comitê da CIO para Organização dos Trabalhadores do Aço (SWOC). Durante o outono e inverno de 1936-37, a nação testemunhou a greve com ocupação dos trabalhadores das indústrias de automóveis de Flint e os interrogatórios no congresso de La Follete sobre os boicotes às greves corporativas e a espionagem anti-sindical. Tão logo começaram os ensaios de Cradle, em março de 1937, a SWOC conseguiu um excelente acordo com a U.S. Steel. O final do musical, no qual cornetas, tambores e pífaros dos caldeireiros davam sinal de que "os trabalhadores do aço estão se reunindo esta noite", parecia ecoar na realidade.

Como descreve a personagem Sophie Silvano, “é como se Cradle Will Rock estivesse na primeira página dos jornais. Greve nas indústrias siderúrgicas... os mesmos temas, quase as mesmas palavras.” Tal seqüência de eventos intensificou ainda mais o interesse pela peça, que atraiu uma platéia receptiva e complacente e possibilitou que, uma semana antes da estréia, quatorze mil ingressos já estivessem vendidos. Nas palavras de Hallie Flanagan, “o teatro, quando é bom, é sempre perigoso.”

Entretanto, não foi só a atenção do público que a peça atraiu. Quando a peça estava para estrear, o Congresso estava considerando realizar um corte de vinte e cinco a trinta por cento nos fundos da WPA. Em resposta às notícias de cortes, os artistas do Federal One passaram a organizar piquetes e ocupações, seguidas de uma interrupção nos trabalhos no dia 27 de maio de 1937. Hallie Flanagan declarou, de acordo com o Times, que

Seja o que for que achemos de seus métodos, nós devemos indagar quais são as razões para o protesto. Eles constataram que seus empregos em perigo ao mesmo tempo em que eles estão provando 
certo grau de utilidade para as vinte milhões de pessoas que nunca tinham ido ao teatro. Eles estão conscientes que, caso eles percam seus empregos eles voltarão para a indigência... é a partir dessa perspectiva que eu peço que vocês observem essa greve. Se vocês desaprovam tal método, eu acredito que deveriam surgir desse encontro algumas sugestões de melhores métodos. ${ }^{69}$

O elenco de The Cradle Will Rock também participou da greve, vivenciando na realidade aquilo que eles vinham ensaiando no palco.

Aos cortes, se seguiu uma ordem de que todas as estréias agendadas para antes de $1^{\circ}$ de julho de 1937 fossem canceladas, o que afetava diretamente à performance de Cradle, cuja início das apresentações estava marcado para 16 de junho. Tal fato, assim como o esforço da equipe do Projeto 891 para realizar a peça, são apresentados no filme. Para Hallie Flanagan, “essa ordem representava mais do que censura. Ela marcou uma mudança de ponto de vista em Washington e tal mudança também se manifestou de outras formas igualmente desastrosas para o projeto."70

Ironicamente, mais obstáculos para a apresentação da peça partiram dos sindicatos a que estavam ligados os atores e músicos do projeto. Tanto o Actors' Equity quanto o American Federation of Musicians faziam parte do American Federation of Labor (AF of L) e não estavam muito entusiasmados com uma ópera que celebrasse o Congress of Industrial Organizations (CIO). Ambos os sindicatos emitiram decisões que tornaram praticamente impossível que seus membros participassem: os músicos deveriam receber o valor de tabela

\footnotetext{
${ }^{69}$ Flanagan, Hallie apud Quinn, Susan. Op.cit., p. 174.

${ }^{70}$ Ibidem
} 
do sindicato e os atores não podiam aparecer no palco, uma vez que estariam violando o acordo do sindicato com a WPA. ${ }^{71}$

Conforme descrevemos no primeiro capítulo desta dissertação, Marc Blitzstein, não sendo membro do sindicato, permaneceu sozinho no palco, que continha apenas um piano, no qual tocava as músicas compostas por ele. Olive Stanton, motivada por suas vivências e reconhecendo a importância de sua atuação naquele momento, levanta-se em meio à platéia e representa sua personagem - Moll - que tanto tem em comum com ela. Incentivados pela atitude da colega de grupo e determinados também pela realidade que vivenciavam, os demais atores levantam, um a um, transformando a representação da peça em algo ainda maior e mais revolucionário do que prometia ser. Observamos de maneira concreta ao fim da distinção entre atores e platéia, que se misturam e se tornam elementos centrais dessa representação. Realiza-se nesse evento a proposta de Walter Benjamin em seu texto O Autor como Produtor: a peça conduz consumidores à esfera da produção, ou seja, transforma os espectadores em colaboradores. Os atores também optam por tomarem uma posição enquanto produtores, sendo fruto de uma escolha a ação de atuar na peça, apesar de tudo que havia de toda a oposição que se impôs.

O que antes era possibilidade para a execução da peça se torna agora seu limite; ou seja, o financiamento do governo federal, que tornou realidade um teatro "livre, adulto e sem censura", restringe a "liberdade" dos artistas, que entra em conflito com os interesses daqueles que estão no poder. Os temas passam a ser limitados, em esfera federal e até mesmo municipal, em alguns casos.

As cenas da apresentação da peça são intercaladas com as de outras narrativas, assim como é característico ao longo de todo o filme. O momento em que aqueles que estão no

\footnotetext{
${ }^{71}$ Para saber mais sobre tais eventos, cf. Flanagan, Hallie. Op.cit. e Quinn, Susan. Op.cit.
} 
poder se reúnem no baile de fantasia é encerrado com a fala de Hearst, que afirma "artistas são prostitutas, como nós". Continuamos vendo as cenas do baile, mas passamos a ouvir a voz de Olive, que canta: "Talvez você fique imaginando / o que torna as pessoas boas ou más". Vemos então imagens do mural de Diego Rivera, enquanto a música continua: "por que um sujeito / um campeão, sem dúvida / se torna um mau-caráter". Voltamos ao teatro, onde vemos Moll sendo levada pelo policial, cantando: "e vice-versa. Eu digo o que sinto / é apenas uma moeda embaixo do sapato". A representação é mais uma vez do mural de Rivera, para o qual trabalhadores se dirigem com andaimes, para iniciar a destruição: "apóie-se no ombro de alguém enquanto o engana / corte a garganta de alguém enquanto investe". A imagem passa a ser do reflexo de Crickshaw em alguns espelhos: "para cada sonho e esquema / dependendo se". Vemos o mural mais uma vez: "durante toda a tempestade / você manteve segura". Olive no teatro:"aquela moeda sob seu pé".

A música funciona como ponte sonora, justamente pontuando os limites que se impuseram a Diego Rivera e Tommy Crickshaw e relacionando tanto os artistas quanto as formas artísticas que eles representam. Ao mesmo tempo, ambos são relacionados com a peça The Cradle Will Rock, que mapeia a prostituição dos mais diversos representantes da sociedade americana no período, inclusos entre eles os artistas. A personagem que não se prostitui na peça é Larry Foreman, cujo nome, assim como de outras personagens é definido a partir de sua profissão (contramestre). Na seqüência final do filme podemos observar o diálogo entre ele e Mr. Mister:

Larry: Você quer que eu alicie todas as pessoas que eu reuni e registrei, todas as pessoas que concordam com a sindicalização? Você quer que eu as faça mudar de idéia. É isso?

Mr. Mister: Eu não diria dessa maneira. 
Larry: Eu devo valer uma boa quantia pra você, né?

Mr. Mister: Foi o que imaginei... todo homem tem seu preço.

Mais uma vez ouvimos Olive cantando, ao mesmo tempo em que vemos a imagem de Crickshaw: "e cada dia é um passeio pela terra das maravilhas". Ele abre a porta e lá está Hazel Huffman. A música continua: "você pode sonhar e planejar / e com alegria investir / então gastar, gastar e investir". Eles se abraçam: "mas primeiro certifique-se / que a moeda está embaixo do seu pé / então se você for doce / depois você vai apodrecer". O plano que a câmera está mostrando se amplia, e observamos um show de malabaristas no palco do vaudeville enquanto ainda vemos Hazel e Tommy abraçados ao fundo do plano. Voltamos ao teatro, onde Larry diz:

Larry: Espere! Estou me sentindo meio esquisito desse jeito. Eu gostaria de saber agora quanto você pagaria para me comprar.

Liberty Committee: Quem você pensa que é? Continue, continue. É o Mr. Mister que está lhe fazendo uma oferta. Aproveite! Aproveite! (Mr. Mister entrega um papel para Larry. A música para e todos, inclusive a platéia, permanecem em silêncio)

Larry: Não me diga! Minha participação vale tudo isso para você?

(Mr. Mister acena com a cabeça que sim)

Larry: Bem, pegue todo esse dinheiro e vai comprar um belo pedaço de pão ${ }^{72}$. E vá embora daqui!

\footnotetext{
72 No original "Go buy yourself a big piece of toast". Optamos por traduzir essa frase de maneira literal, mas convém ressaltar que há uma expressão cuja relação pode ser também estabelecida com o que Larry responde: have someone on the toast, que significa "exercer domínio sobre alguém”. Desse modo, ao mesmo tempo em que ele diz para o manda -chuva fazer o que bem entendesse com o dinheiro, também está dizendo que se quiser mandar em alguém, vai ter que procurar outra pessoa para comprar.
} 
É interessante relacionar esse diálogo e a caracterização da personagem Aldo Silvano, que interpreta Larry Contramestre na peça. Desde o começo do filme, ele marca fortemente seu posicionamento político e apego aos seus ideais, chegando ao ponto de passar por dificuldades junto com sua família, para não ter que aceitar que seus filhos fossem influenciados por idéias fascistas de seus familiares. Em certo momento, conversa com sua esposa, Sophie:

Sophie: Sabe quem veio aqui? Sua mãe. Ela ficou bem chocada com o modo como estamos vivendo.

Aldo: Ela ficaria mesmo.

Sophie: Eu acho que ela quer ajudar.

Aldo: Não.

Sophie: Aldo, esse dinheiro poderia ser bem útil para nós.

Aldo: Eu não quero o dinheiro da minha família.

Sophie: Então as crianças tem que passar fome por causa de sua dignidade, de suas visões políticas?

Aldo: Você quer que eles se tornem "fascistinhas bochechudos"?

Sophie: Não! Como você pode dizer isso? Mas eu também não quero ficar em filas de sopa com eles.

Aldo: O que nós estaríamos ensinando se pegássemos o dinheiro de meus pais? É certo acreditar em algo ou ter dignidade, mas se você estiver um pouco desconfortável ou faminto, venda-se.

Sophie: Aldo, há ratos aqui dentro.

Mesmo diante das condições precárias que viviam, ele opta por manter-se fiel aos seus ideais e não aceitar o dinheiro de seus pais. Estabelecendo uma relação com a personagem que ele interpreta na peça, observamos um movimento semelhante ao que descrevemos em relação a Olive Stanton, a reprodução na ficção de sua realidade cotidiana, a inserção de sua história de 
vida na história da personagem, o que permite uma dupla reflexão por parte dos espectadores do filme, que têm a possibilidade de ver além do que a platéia da peça observa, com a perspectiva do que ocorre dentro do teatro, complementada com o conhecimento que acumularam ao longo do filme. Por outro lado, o público que assiste à peça é, como dissemos, composto de Olives (e poderíamos acrescentar que também de Aldos). Desse modo, ao assistirem à representação da peça, compartilham das mesmas vivências que nós apenas observamos enquanto espectadores. Eles se tornam assim parte de própria narrativa, deixando de ter papel de espectador e passando a ser parte daquele evento que acompanham. Tal aspecto se intensifica por conta do fato de que os atores atuam em meio à platéia, conforme já apontamos.

Outro aspecto importante a ser destacado é o fato de que nós, ao vermos o filme, temos uma perspectiva que vai mais longe, uma vez que enquanto o sindicalista da peça não se prostitui, os sindicalistas reais se prostituíram, do mesmo modo que os representantes das demais esferas da sociedade, proibindo os músicos e atores de atuarem na peça, que por ironia (ou não) é pró-sindicalista.

Voltando ao teatro, podemos descrever a resposta de Larry Contramestre ao Liberty Committee e seus gritos de "Linche-o! Mate-o!". Ele diz:

Ouçam de uma vez por todas, seu bando de medrosos. Lá fora na praça, eles estão começando algo que vai fazer vocês se arrepiarem de medo. É o aço marchando à frente. As pessoas dessa cidade estão começando a entender o "espírito da coisa". Eles estão ganhando força. E quando todos se unirem como os trabalhadores das siderúrgicas estão fazendo hoje, onde vocês vão parar? Ouçam, seus mal-feitores da Ku Klux Klan. Cheios, de cautela, se escondendo nos 
braços do Liberty Commitee. Quando a tempestade avançar, o poder vai dançar.

Ouvimos em seguida uma nova música, cantada por um grupo de pessoas: "e então eles levantam a mão / e sentem o clima tempestuoso". A imagem mostrada é agora de Melvin, o boneco de Crickshaw, em um caixão em cuja lápide está escrito Federal Theatre, nascido em 1934, falecido em 1937: “um pássaro voa e lamenta 'a coisa está preta' / vocês não quiseram ver / agora vão se arrepender". Enquanto ouvimos esse trecho, Sid e Larry, os pupilos de Crickshaw, levantam o caixão e são seguidos por outras pessoas, vestidas com figurinos que sugerem que faziam parte do projeto. A música ainda continua: "são trovões / são relâmpagos". Observamos a destruição do mural de Rivera: "e vão rodear você / não me surpreende que esses pássaros / parecem estar em volta de você / bem, você não pode descer I nem ficar sentado parado”. Cenas do cortejo fúnebre do Federal Theatre: “esta é uma tempestade que vai durar / até o vento final soprar / e quando o vento final soprar". Voltamos ao teatro, onde todos os atores da peça estão agrupados, bem próximos ao palco e cantam juntos e em um tom bem alto: “O poder vai dançar!’. Repetem o refrão, se misturando ao público, que vibra intensamente e aplaude ao mesmo tempo, enquanto ouvimos: "são trovões / são relâmpagos / e vão rodear você / não me surpreende que esses pássaros / parecem estar em volta de você / bem, você não pode descer / nem ficar sentado parado / essa é uma tempestade que vai durar / até o vento final soprar / e quando o vento final soprar / O poder vai dançar / O poder vai dançar!".

Por fim, passamos a ouvir uma música bem alegre, enquanto observamos as personagens celebrando a vitória obtida com a apresentação da peça. São mais uma vez intercaladas cenas do mural, no qual só restou a célula contaminada com sífilis; do cortejo do Federal Theatre e do teatro, todas relacionadas através de uma ponte sonora. Marc Blitzstein 
é levantado pelos colegas, como um herói. Há um close no rosto de Olive, que é substituída na seqüência pelo boneco Melvin, o que gera uma equivalência entre eles. A conclusão da seqüência (e do filme) mostra que o cortejo fúnebre termina na Times Square ${ }^{73}$ no momento presente, enquanto a música parece desafinar, em tom agudo.

Analisando esses últimos aspectos apontados, podemos dizer que o cineasta problematiza essa celebração da vitória alcançada com a peça The Cradle Will Rock, demonstrando que tal vitória se restringe ao interior do teatro, enquanto o mural de Rivera foi destruído e o próprio projeto a que está ligada a peça foi encerrado. Isso não quer dizer que seja um final pessimista, que demonstra que o resultado de todo esse processo é a Times Square - símbolo da indústria do entretenimento -, mas sim um apontamento de que é necessário transcender os limites do teatro, para que haja uma mudança efetiva na sociedade.

\footnotetext{
${ }^{73}$ A área está localizada na junção da Broadway com a 7ạ Avenida, na região central de Manhattan. É uma área comercial, onde todos os prédios são obrigados a instalar letreiros luminosos, para propósitos de publicidade. Na Times Square está localizada a NASDAQ, uma das principais bolsas de valores do mundo. Entre seus pontos comerciais mais conhecidos estão os estúdios da rede de televisão $A B C$, bem como os famosos estúdios da MTV e da Virgin Records. O local possui uma das maiores concentrações da indústria do entretenimento no mundo, além de grandes lojas de famosas marcas internacionais.
} 


\section{Conclusão: A História de $O$ poder vai dançar}

Tim Robbins afirmou, em entrevista a respeito de $O$ Poder Vai Dançar, que seu ponto de partida foi a cena final, na qual observamos os atores e músicos que, impedidos de subir no palco pelos próprios sindicatos, decidem, no calor do momento, levantar da platéia e atuar no meio dela. Esse evento, como já apontamos, é resultado do contexto histórico em que estão inseridos, e a atitude inicial partiu de uma dentre aqueles tantos que fortemente sentiam a pressão da História. A ela se seguem os demais atores e músicos que, fazendo parte dessa experiência, também são impulsionados pela própria História, que invade o teatro e a vida de cada uma das personagens.

Desse modo, buscamos pontuar, ao longo desta dissertação, a importância que a História possui na construção das narrativas presentes no filme, assim como na estruturação dele como um todo. Conforme afirmamos, antes de qualquer ação já são apresentados elementos históricos relacionados ao período retratado. Entretanto, tais fatos não estão presentes como um pano de fundo para as ações, mas sim como elemento estrutural das cenas e do filme, nos quais temos coletividades atuando e não personagens individualizadas. Sendo assim, a História funciona como princípio organizador da cena, ou seja, ao invés de estar a serviço da história dos personagens, coloca as personagens a serviço da História. Contudo, o cineasta não pretende realizar um grande panorama que se diria "objetivo" da década de 1930 nos Estados Unidos, haja vista que são feitos recortes apenas de aspectos relacionados às teses que o filme pretende tratar. Segundo o próprio cineasta, "O truque em realizar uma obra de época é fazer que seja convincente para o público. Além dos penteados e figurino, você tem 
que mostrar que é a mesma velha história"74.

Podemos destacar entre os principais teoremas apresentados no filme o citado aspecto, da História funcionando como elemento estrutural das narrativas e do longametragem como um todo. Ao mesmo tempo, o cineasta propõe uma reflexão acerca da condição do artista enquanto proletário da cultura, fazendo uma espécie de mapeamento de diversas posições em relação a essa questão.

Marc Blitzstein, por exemplo, é mostrado desde o primeiro momento como um trabalhador, havendo uma preocupação em assinalar o processo de composição de The Cradle Will Rock, o que é complementado pela reflexão que a peça composta por ele propõe. Olive Stanton passa por um processo de conscientização e amadurecimento político, que são frutos de uma reflexão baseada nas condições materiais em que se encontra. De modo semelhante, Aldo Silvano, ao final da narrativa, percebe seu trabalho como um meio de sobrevivência. Porém, ainda assim decide atuar na seqüência final, colocando tudo isso em risco por reconhecer a importância política da peça. Os demais atores do Projeto 891 parecem estar conscientes do fato de serem trabalhadores desde o início do filme, uma vez que são sindicalizados e exercem seus direitos. John Adair, por outro lado, aponta para uma dimensão de alienação em relação ao trabalho que realiza. Por intermédio da representação da personagem Tommy Crickshaw, o cineasta demonstra que a simples conscientização da condição de trabalhador por parte do artista não gera automaticamente uma posição progressista por parte do mesmo. O ventríloquo opta por se alienar de sua função política e, ao fazê-lo contribui para a destruição da arte que representa. Diego Rivera, de modo oposto, mantém suas convicções políticas acima de tudo, sem levar em consideração as relações de produção a que está submetido, e tem seu mural destruído ao final.

\footnotetext{
${ }^{74}$ Cooper, Marc. Tim Robbins: Rocking the establishment. Mother Jones Magazine, v. 25, n. 1, p. 82, 2000.
} 
O cineasta Tim Robbins, que contou com financiamento de Hollywood para a realização de O Poder Vai Dançar, disse à platéia de Cannes, na premiére desse filme, em 1999 que "se preocupava com a linha entre fazer arte [paga por empresas] e prostituição."75 Esse é mais um dos teoremas que se colocam no decorrer de todo o filme.

Quando questionado a respeito de sua própria prostituição, ao receber financiamento da Disney para realização de $O$ Poder Vai Dançar, o cineasta afirma:

Eu sou muito afortunado porque eu tenho uma carreira como ator e não preciso trabalhar como diretor. Não vale a pena para mim me comprometer, porque eu posso desistir facilmente, sem ter que enfrentar as conseqüências, por ter uma carreira de garantia. ${ }^{76}$

Apesar de seu financiamento, Tim Robbins assume uma posição no processo produtivo ao lado do proletariado, uma vez que privilegia na montagem do filme aspectos do mundo do trabalho e, ao mesmo tempo, marca fortemente sua posição política progressista.

A pergunta que nos resta responder é: Por que escolher exatamente a década de 1930? Por que esses eventos em específico?

A resposta está no que há em comum entre esse momento histórico e aquele em que o filme foi produzido, a década de 1990. Ambos compartilham contextos históricos semelhantes, em termos de potencialidades e de limites que se impõem. Constituem o que Benjamin define como momentos de constelação, que ligam o presente e o passado, e que são constituídos de fatos arrancados da continuidade histórica, representando uma chance 
revolucionária no combate hoje contra o passado oprimido e também contra o presente oprimido.

Conforme já exposto, na década de 1930 os Estados Unidos viviam a Grande Depressão, momento em que o desemprego passou de meio milhão para quatro milhões de pessoas em poucos meses, e para um terço da população economicamente ativa em poucos anos. As filas para doação de sopa e pão se espalhavam por todos os lugares. E os investimentos caíram em cerca de noventa e oito por cento. Segundo Tim Robbins, "apesar de economicamente sitiados, os americanos estavam de forma alguma politicamente paralisados" $" 77$. De acordo com Richard Cloward e Frances Piven,

trabalhadores das fábricas tiveram sua maior influência e conseguiram atingir as maiores concessões do governo durante a Grande Depressão, nos anos que antecederam a sindicalização. Seu poder durante esse período não se originava na organização, mas sim na ruptura. ${ }^{78}$

Dessa forma, os fatos históricos serviram como combustível para um despertar político de várias camadas da população americana, que sofriam as conseqüências da Grande Depressão. Durante esse período, o presidente Roosevelt criou o New Deal, com o objetivo de recuperar e reformar a economia norte-americana. Uma das divisões do New Deal era a WPA, especificamente para criar empregos nas mais diversas áreas. O Federal Theater, um de seus projetos, possibilitava empregar artistas, escritores e diretores fora do mercado de trabalho, entreter famílias economicamente impossibilitadas de ter acesso a arte, ao mesmo tempo que patrocinava arte relevante, financiando teatro e outras performances artísticas. $\mathrm{O}$

\footnotetext{
${ }^{77}$ Robbins \& Burns. Op.cit., p.12.

${ }^{78}$ Cloward, Richard; Piven, Francis apud Zinn, Howard. Op.cit., p.402.
} 
financiamento por parte do governo possibilitou a criação de uma estrutura de âmbito nacional, que durante dois anos e meio praticamente monopolizou as atenções do teatro no país. Segundo Iná Camargo Costa, este elemento positivo do FTP foi também o seu fim, já que a política do New Deal tinha que evitar a identificação do governo com o Partido Comunista e portanto fechou o projeto em junho de 1939.

Tim Robbins retrata um período em que haveria um grande potencial de revolução popular. Neste período, os principais porta-vozes do marxismo, ideólogos da II e III Internacional percebiam a história como um tipo de máquina que conduz "automaticamente" ao triunfo do socialismo. O desenvolvimento das forças produtivas, o progresso econômico e as "leis da história" levariam necessariamente à crise final do capitalismo e à vitória do proletariado.

Parte então de um momento posterior, em que a revolução, que seria algo "natural", não aconteceu. O contexto político da produção do filme $O$ poder vai dançar, 1999, é um momento posterior à gestão de Reagan, de submissão das políticas fiscais a interesses corporativos. Muitos progressistas de Hollywood confiavam que a eleição de Clinton transformaria tudo isso, acreditando em sua retórica liberal bastante sedutora. No entanto, ele rendeu-se ao conservadorismo, reforçando as políticas retrógradas estabelecidas por Reagan, e assinando diversas leis que agradariam mais o Partido Republicano e às grandes empresas do que aos democratas, que ainda evocavam Roosevelt como uma espécie de inspiração. Por falar em Roosevelt, Clinton reduziu também enormemente medidas de bem-estar social conquistadas a partir daquele momento histórico, concentrando todos seus esforços para promover a Globalização.

Surgiu então no final da década de 1990 um significativo movimento popular, representado em protestos localizados contra a mídia, contra determinadas corporações ou ainda contra leis que retroagiam direitos adquiridos. Esse movimento foi ganhando força e 
outras demandas, como o protesto contra a guerra e por fim os protestos anti-globalização. Uma efervescência geral de protestos, greves, movimentos organizados de trabalhadores das mais diversas áreas, que fazia nascer entre aqueles que deles participavam uma nova esperança de transformações.

As cenas do filme que mostram os protestos de trabalhadores no Central Park evocam episódios reais, que Robbins presenciou durante os protestos de que participou ativamente em Seattle, onde milhares de pessoas mobilizaram-se por vários dias e manifestaram-se contrários à globalização durante a reunião da Organização Mundial do Comércio (OMC) em 1999. Inclusive a repressão policial, com uso de gás lacrimogêneo para afugentar os manifestantes também remete a estes eventos. Essas e outras manifestações são concomitantes ou posteriores ao filme, e estavam no mínimo se constituindo como forte movimento de oposição à situação vigente.

Percebemos então que ambos os momentos históricos tiveram as expectativas políticas frustradas por limites impostos pelo capital e pelos que detém o poder. O cineasta retorna a esse momento passado, na busca de compreender o que havia de interessante e que deu errado nesse projeto da década de 1930; e como o potencial artístico e revolucionário, representado na peça The Cradle will rock, para citar um dos muitos exemplos existentes no filme, foi dar em Broadway.

Mas muito mais do que isso, Tim Robbins faz então o que Benjamin define como um "salto de tigre em direção ao passado", um salto dialético sob o livre céu da história, ao se apropriar de um momento explosivo do passado, carregado de "tempo de agora", utilizando a citação do passado como fonte de inspiração, arma cultural poderosa no combate presente. Esta conduta do materialismo histórico descobre as energias explosivas ocultas que se encontram em um momento preciso da história. Essas energias, do "tempo-de-agora" (jetzteit) 
são como a faísca que sai de um curto-circuito, permitindo "fazer explodir" a continuidade histórica.

Estabelece-se então um movimento dialético, em que o presente ilumina o passado, e o passado, iluminado, torna-se uma força no presente. Ambos assumem novas formas em decorrência desta relação: o passado, que poderia ter sido apagado, é revivido; e o presente se constitui enquanto realização possível da promessa anterior.

Este diálogo entre passado e presente não acontece apenas em termos dos fatos que os relacionam ou diferenciam, ou em termos do desenvolvimento das forças produtivas e da contradição entre forças produtivas e relações de produção, mas principalmente em termos da luta entre opressores e oprimidos, exploradores e explorados, dominantes e dominados. 


\section{Referências}

Adorno, T; Horkheimer. "A Indústria Cultural: O Esclarecimento como Mistificação das Massas". In: Dialética do esclarecimento. Disponível em http://antivalor.vilabol.uol.com.br

Aguena, Paulo (org.). O marxismo e os sindicatos. São Paulo: Sundermann, 2008.

Bazin, André. Orson Welles. Lisboa: Horizonte, 1991.

Benjamin, Walter. Conversaciones com Brecht. In: Tentativas sobre Brecht. Taurus Humanidades.

Benjamin, Walter. Obras escolhidas - Magia e técnica, arte e política: ensaios sobre literatura e história da cultura. São Paulo: Brasiliense, 1994.

Blitzstein, Marc. The cradle will rock. Fairfax: Library of Congress Theatre Project Collection, 1936.

Bordwell, David. Mutual Friends and Chronologies of Chance. In: Poetics of cinema. New York: Routledge, 2007.

Bordwell, David. Narration in the fiction film. London: Methuen \& Co. Ltd., 1985.

Bortulucce, Vanessa Beatriz. A arte dos regimes totalitários do século XX: Rússia e Alemanha. São Paulo: Annablume, Fapesp, 2008

Brecht, Bertolt. Teatro dialético. Rio de Janeiro: Editora Civilização Brasileira, 1967. 
Brecht, Bertolt. The Threepenny Material. In: Silberman, Marc D. Brecht On Film \& Radio. London: Methuen Drama, 2000.

Callow, Simon. Orson Welles: the Road to Xanadu. London: J.Cape, 1995.

Carvalho, Sérgio de. Introdução ao teatro dialético: experimentos da Companhia do Latão. São Paulo: Expressão Popular, 2009.

Cevasco, Maria Elisa; Soares, Marcos. Crítica cultural materialista. São Paulo: Humanitas, 2008.

Cooper, Marc. Tim Robbins: Rocking the establishment. Mother Jones Magazine, v. 25, n. 1, 2000

Costa, Iná Camargo. Brecht no cativeiro das forças produtivas.(não publicado)

Costa, Iná Camargo. Panorama do Rio Vermelho: ensaios sobre o teatro americano moderno. São Paulo: Nankin Editorial, 2001.

Debord, Guy. A sociedade do espetáculo. Contraponto, 1997.

Denning, Michael. The Cultural Front: the laboring of American Culture in the Twentieth Century. London: Verso, 1996.

Dickenson, Ben. Hollywood's New Radicalism: War, Globalisation and the Movies from Reagan to George W. Bush (Cinema and Societ).I. B. Tauris, 2006.

Drehle, Dave Von. Triangle: the fire that changed America. New York: Atlantic Monthly Press, 2003.

Eisenstein, Sergei. A forma do filme. Rio de Janeiro: Jorge Zahar Editor. 
Flanagan, Hallie. Arena. New York: Duell, Sloan and Pearce, 1940.

Garraty, John A. apud Schivelbusch, Wolfgang. Three new deals: reflections on Roosevelt's America, Mussolini’s Italy and Hitler's Germany, 1933-1939. New York: Picador, 2006.

Kettenmann, Andrea. Diego Rivera (1886-1957): un espíritu revolucionario en el arte moderno. Köln: Taschen, 2006.

Klein, Andy. Review of the movie Cradle will rock, disponível em http://www.riverfronttimes.com/2000-01-19/film/cradle-will-rock/2

Lewis, Robert M. From traveling show to vaudeville: theatrical spetacle in America, 18301910. Baltimore: The John Hopkins University Press, 2003

Lowy, Michael. Para uma sociologia dos intelectuais revolucionários. São Paulo: Lech Livraria Editora Ciências Humanas, 1979.

Lowy, Michael. Walter Benjamin: aviso de incêndio - uma leitura das teses "Sobre o conceito de história”. Tradução: Wanda Nogueira Caldeira Brant. São Paulo: Boitempo, 2005.

Martorella, Rosanne. Art and business: an international perspective on sponsorship. Westport: Greenwood Publishing Group, 1996

Marx, Karl. Contribuição à crítica da economia política. São Paulo: Martins Fontes, 2003.

Marx, Karl; Engels, Friedrich. A ideologia alemã. Editorial Grijalbo, 1977.

Marx, Karl. Manuscritos econômico-filosóficos. São Paulo: Martin Claret, 2006. 
Maslin, Janet. Cradle Will Rock': Panoramic Passions on a Playbill From the 30's. disponível em http://www.nytimes.com/library/film/120899cradle-film-review.html

McCarthy, Todd. Resenha sobre o filme $O$ Poder Vai Dançar, disponível em http://www.variety.com/review/VE1117499758.html?categoryid=31\&cs=1

Quinn, Susan. Furious improvisation: how the WPA and a cast of thousands made high art out of desperate times. New York: Walker \& Company, 2008.

Quinsani, Rafael Hansen. A revolução na encruzilhada: uma análise da arte revolucionária do muralismo mexicano a partir da imagem O homem controlador do universo, de Diego Rivera. História, imagem e narrativas, n.11, out/2010. Disponível em: http://www.historiaimagem.com.br

Rhodes, Steve. Movie Review for Cradle Will Rock. Disponível em http://www.celebritywonder.com/movie/1999 Cradle Will Rock steve rhodes.html

Robbins, Tim; Burns, Theresa. Cradle Will Rock: The Movie and the Moment. New York: Newmarket Press, 1999.

Rosenfeld, Anatol. O teatro épico. São Paulo: Editora Perspectiva, 2002.

Schwartz, Dennis. The unfortunate thing about the film, is that it is not terribly entertaining. Disponível em http://www.sover.net/ ozus/cradlewillrock.htm

Scott, Robert L. Diego Rivera at Rockefeller Center: Fresco Painting and Rhetoric. Western Journal of Speech Communication, n. 41, Spring 1977, p. 70-82. Disponível em: http://web.utk.edu/ glenn/Scott-Rivera.pdf

Silberman, Marc. Brecht on film and radio. London: Methuen Publishing Ltd, 2000. 
Smith, Wendy. Real life drama: the Group Theatre and America, 1931-1940. New York: Grove Weindenfeld, 1992.

Sterrit, D. (org.). Robert Altman: Interviews. Jackson: University Press of Mississippi, 2000. p.129.

Szondi, Peter. Teoria do drama moderno.. São Paulo, Cosac \& Naify Edições, 2001.

WALSH, Martin. The complex seer: Brecht and the film. In: The Brechtian Aspect of Radical Cinema. London: BFI Publishing, 1981.

Willet, John. O teatro de Brecht: visto de oito aspectos. Rio de Janeiro: Zahar Editores.

Xavier, Ismail. O olhar e a cena. São Paulo, Cosac \& Naify, 2003.

Zinn, Howard. A people's history of the United States. New York: Harper Perennial Modern Classics, 2003. 